\title{
Mercuric pollution of surface water, superficial sediments, Nile tilapia (Oreochromis nilotica Linnaeus 1758 [Cichlidae]) and yams (Dioscorea alata) in auriferous areas of Namukombe stream, Syanyonja, Busia - Uganda
}

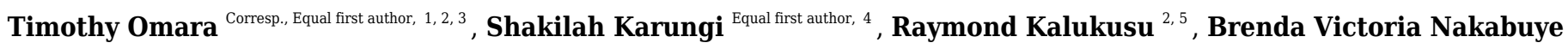 \\ 5,6 , Sarah Kagoya ${ }^{2,7}$, Bashir Musau ${ }^{2,5}$ \\ ${ }^{1}$ Department of Chemistry and Biochemistry, School of Biological and Physical Sciences, Moi University, Uasin Gishu County, Kesses, Eldoret, Kenya \\ 2 Department of Chemistry, Faculty of Science, Kyambogo University, Kampala, Kyambogo, Uganda \\ 3 Department of Quality Control and Quality Assurance, Product Development Directory, AgroWays Uganda Limited, Jinja, Kyabazinga way, Uganda \\ 4 Department of Mining and Water Resources Engineering, Faculty of Engineering, Busitema University, Tororo, Busitema, Uganda \\ 5 Department of Quality Control and Quality Assurance, Leading Distillers Uganda Limited, Kampala, Uganda \\ 6 Department of Food Processing Technology, Faculty of Science, Kyambogo University, Kampala, Uganda \\ 7 Department of Quality Control and Quality Assurance, Product Development Directory, Sweets and Confectionaries Section, Kakira Sugar Limited, Jinja, \\ Uganda \\ Corresponding Author: Timothy Omara \\ Email address: prof.timo2018@gmail.com
}

The mercury content and the contamination characteristics of water, sediments, edible muscles of a non-piscivorous fish (Oreochromis nilotica Linnaeus 1758 [Cichlidae]) and yams (Dioscorea alata) from Namukombe stream in Busia gold district of Uganda were evaluated. Human health risk assessment from consumption of contaminated fish and yams as well as contact with contaminated sediments from the stream were performed. Forty-eight (48) samples of water $(n=12)$, sediments $(n=12)$, fish $(n=12)$ and yams ( $n$ $=12$ ) were taken at intervals of $10 \mathrm{~m}$ from three gold recovery sites located at up, middle and down sluices of the stream and analyzed for total mercury (THg) using US EPA method 1631. Results (presented as means \pm standard deviations) showed that water in the stream is polluted with mercury in the range of < detection limit to $1.21 \pm 0.040 \mathrm{mg} / \mathrm{L}$

while sediments contain mean THg from < detection limit to $0.14 \pm 0.040 \mathrm{ugg}^{-1}$. Mean THg content of the edible muscles of $O$. nilotica ranged from < detection limit to $0.11 \pm 0.014$ $u g^{-1}$ while $D$. alata contained from < detection limit to $0.30 \pm 0.173 u g^{-1}$ mean $\mathrm{THg}$. The estimated daily intake ranged from $0.0049 \mathrm{ugg}^{-1}$ day $^{-1}$ to $0.0183 \mathrm{ugg}^{-1}$ day $^{-1}$ and 0.0200 $u g^{-1}$ day $^{-1}$ to 0.0730 ugg $^{-1}$ day $^{-1}$ for fish consumed by adults and children respectively. The corresponding health risk indices ranged from 0.0123 to 0.0458 and 0.0500 to 0.1830 .

Estimated daily intake was from 0.0042 ugg $^{-1}$ day $^{-1}$ to 0.1279 ugg $^{-1}$ day $^{-1}$ and 0.0130 Peer) reviewing PDF | (2019:06:38591:2:0:ACCEPTED 16 Sep 2019) 
$u_{\mathrm{gg}}{ }^{-1}$ day $^{-1}$ to $0.3940 \mathrm{ugg}^{-1} \mathrm{day}^{-1}$ for $D$. alata consumed by adults and children respectively. The health risk indices recorded were from 0.011 to 0.320 and 0.033 to 0.985 for adults and children respectively. The mean THg content of the sediments, edible muscles of $O$. nilotica and $D$. alata were within acceptable WHO/US EPA limits. About $91.7 \%$ of the water samples had mean THg above US EPA maximum permissible limit for mercury in drinking water. Consumption of $D$. alata grown within $5 \mathrm{~m}$ radius up sluice of Namukombe stream may pose deleterious health risks as reflected by the health risk index of 0.985 being very close to one. From the pollution and risk assessments, mercury use should be delimited in Syanyonja artisanal gold mining areas. Solution to abolish mercury-based gold mining in the area need to be sought as soon as possible to avert the accentuating health, economic and ecological disaster arising from the continuous discharge of mercury into the surrounding areas. Other mercury-free gold recovering methods such as use of borax, sluice boxes and direct panning should be encouraged. Waste management system for contaminated wastewater, used mercury bottles and tailings should be centralized. 


\section{Mercuric pollution of surface water, superficial sediments,}

2 Nile tilapia (Oreochromis nilotica Linnaeus 1758 [Cichlidae])

3 and yams (Dioscorea alata) in auriferous areas of

4 Namukombe stream, Syanyonja, Busia - Uganda

5 Timothy Omara ${ }^{1,2,3}$, Shakilah Karungi ${ }^{4}$, Raymond Kalukusu ${ }^{2,5}$, Brenda Victoria Nakabuye ${ }^{5,6}$,

6 Sarah Kagoya ${ }^{2,7}$, Bashir Musau ${ }^{2,5}$

$7 \quad{ }^{1}$ Department of Chemistry and Biochemistry, School of Biological and Physical Sciences, Moi

8 University, Uasin Gishu County, Kesses, Eldoret, Kenya

$9 \quad{ }^{2}$ Department of Chemistry, Faculty of Science, Kyambogo University, Kyambogo, Kampala,

10 Uganda

${ }^{3}$ Department of Quality Control and Quality Assurance, Product Development Directory, AgroWays Uganda Limited, Jinja, Uganda

${ }^{4}$ Department of Mining and Water Resources Engineering, Faculty of Engineering, Busitema University, Tororo, Busitema, Uganda

${ }^{5}$ Department of Quality Control and Quality Assurance, Leading Distillers Uganda Limited, Kampala, Uganda

${ }^{6}$ Department of Food Processing Technology, Faculty of Science, Kyambogo University, Kyambogo, Kampala, Uganda

${ }^{7}$ Department of Quality Control and Quality Assurance, Product Development Directory, Sweets and Confectionaries Section, Kakira Sugar Limited, Jinja, Uganda

Corresponding Author:

Timothy Omara 1,2,3

Africa Center of Excellence II in Phytochemicals, Textile and Renewable Energy, Moi University, Uasin Gishu County, Kesses, Eldoret-Kenya

Email address: prof.timo2018@gmail.com

\section{Abstract}

29

30

31

32

33

34

35

36

37

The mercury content and the contamination characteristics of water, sediments, edible muscles of a non-piscivorous fish (Oreochromis nilotica Linnaeus 1758 [Cichlidae]) and yams (Dioscorea alata) from Namukombe stream in Busia gold district of Uganda were evaluated. Human health risk assessment from consumption of contaminated fish and yams as well as contact with contaminated sediments from the stream were performed. Forty-eight (48) samples of water ( $\mathrm{n}=$ 12), sediments $(n=12)$, fish $(n=12)$ and yams $(n=12)$ were taken at intervals of $10 \mathrm{~m}$ from three gold recovery sites located at up, middle and down sluices of the stream and analyzed for total mercury (THg) using US EPA method 1631. Results (presented as means \pm standard deviations) showed that water in the stream is polluted with mercury in the range of $<$ detection limit to $1.21 \pm 0.040 \mathrm{mg} / \mathrm{L}$ while sediments contain mean $\mathrm{THg}$ from $<$ detection limit to $0.14 \pm$ 
$0.040 \mu \mathrm{gg}^{-1}$. Mean THg content of the edible muscles of $O$. nilotica ranged from $<$ detection limit to $0.11 \pm 0.014 \mu \mathrm{gg}^{-1}$ while $D$. alata contained from $<$ detection limit to $0.30 \pm 0.173 \mu \mathrm{gg}^{-1}$ mean THg. The estimated daily intake ranged from $0.0049 \mu \mathrm{gg}^{-1} \mathrm{day}^{-1}$ to $0.0183 \mu \mathrm{gg}^{-1} \mathrm{day}^{-1}$ and 0.0200 $\mu \mathrm{gg}^{-1} \mathrm{day}^{-1}$ to $0.0730 \mu \mathrm{gg}^{-1} \mathrm{day}^{-1}$ for fish consumed by adults and children respectively. The corresponding health risk indices ranged from 0.0123 to 0.0458 and 0.0500 to 0.1830 . Estimated daily intake was from $0.0042 \mu \mathrm{gg}^{-1} \mathrm{day}^{-1}$ to $0.1279 \mu \mathrm{gg}^{-1} \mathrm{day}^{-1}$ and $0.0130 \mu \mathrm{gg}^{-1} \mathrm{day}^{-1}$ to $0.3940 \mu$ $\mathrm{gg}^{-1} \mathrm{day}^{-1}$ for $D$. alata consumed by adults and children respectively. The health risk indices recorded were from 0.011 to 0.320 and 0.033 to 0.985 for adults and children respectively. The mean THg content of the sediments, edible muscles of $O$. nilotica and D. alata were within acceptable WHO/US EPA limits. About $91.7 \%$ of the water samples had mean THg above US EPA maximum permissible limit for mercury in drinking water. Consumption of $D$. alata grown within $5 \mathrm{~m}$ radius up sluice of Namukombe stream may pose deleterious health risks as reflected by the health risk index of 0.985 being very close to one. From the pollution and risk assessments, mercury use should be delimited in Syanyonja artisanal gold mining areas. Solution to abolish mercury-based gold mining in the area need to be sought as soon as possible to avert the accentuating health, economic and ecological disaster arising from the continuous discharge of mercury into the surrounding areas. Other mercury-free gold recovering methods such as use of borax, sluice boxes and direct panning should be encouraged. Waste management system for contaminated wastewater, used mercury bottles and tailings should be centralized.

\section{Introduction}

For centuries, the most precious and enigmatic metals (mercury and gold) have been linked both chemically and in utilization by man due to their demonstrated propensity to produce an amalgam when mixed [1]. Mercury $(\mathrm{Hg})$ on the other hand received further recognition for its toxicity when used in gold recovery since the Roman times [1]. As such, increase in the price of gold, lack of regulation, chronic unemployment and increasing poverty have led to an explosive growth in global artisanal and small-scale gold mining (ASGM) in the last century. The activity is emerging as a significant socio-economic sector with the result that it has become a major source of revenue for more than 100 million people in over 80 countries of Sub-Saharan Africa, Asia, Oceania, Central and South America [2]. This is because it involves low or no capital investment and mechanization, and in most cases the sector is not taxed by national revenue authorities.

Globally, ASGM is the single largest demand for mercury and thus the largest source of intentional pollution of air and water combined [3]. In Uganda, ASGM was conservatively estimated to employ over 60,000 vulnerable people as of 2016 [4]. ASGM is being practiced in the gold districts of Mubende, Namayingo, Bugiri, Mayuge, Busia, Buhweju, Bushenyi, Ibanda, Kanungu, Moroto, Abim, Kaabong, Nakapiripirit and Amudat [4]. Gold in Uganda was first reported in West Nile in 1915 though no mining commenced until 1933. In Busia, gold was reported in 1932 by Davis in Osipiri area (Neoarchean Busia-Kakamega granite greenstone belt) [5] which registered intermittent ASGM on vein and alluvial deposits in Tiira, Makina, 
79 Amonikakine and Osapiri villages up-to-date [4]. The belt is an extension of the northern 80 Tanzanian greenstone belt where gold occur in association with quartz veins. Thus, mercury81 based ASGM was introduced in the 1990s by Ugandans who remigrated into Uganda from the 82 Tanzanian greenstone belt [4]. Unlike the small mechanized processing centres in Tanzania, 83 miners in Busia use manual methods characterized by pounding of auriferous materials, hand 84 amalgamation in basins (panning), open air burning over fires and haphazard discharge of 85 tailings into waterways. Panning is a simple process which separate particles of greater specific 86 gravity (such as gold) from soils, gravels and sediments using water in a dish called a pan.

Despite the fact that rudimentary tools are employed, ASGM in Busia has continued, an indication that the business is recovering sizeable quantities of gold nuggets [4]. More so, the price of gold now exceed US \$1,600 per ounce (from less than US \$500 in the 1980s), causing ASGM to rise along with its elemental mercury pollution [6]. A report from Bank of Uganda cited gold as the second most important export of Uganda after coffee with a worth of US \$ 35.73 million in 2015 and US \$ 339.54 million in 2016 [7].

In Busia and Bugiri districts, close to 1,000 gold miners engage in mercury-based ASGM with $150 \mathrm{~kg}$ of mercury per annum reported to end up in the downstream areas [3]. Approximately, 45 gravity concentration of auriferous materials (panning) [3]. Miners are thus exposed to elemental mercury intoxication [8] as well as cyanide used to extract gold from tailings. Similarly, miners handling mercury used for amalgamation and those living in close proximity to uncontrolled mercury-based gold recovering sites risk coming in contact with mercury through dermal adsorption during amalgamation, inhalation of mercury vapor, drinking mercury-polluted water and consumption of food such as fish, yams, maize, millet and potatoes grown in mercurycontaminated water and soils. decades have been diagnosed with severe health complications including paralysis [9]. The miners do not use any form of personal protective equipment while using mercury [9] which is contrary to international guidelines on mercury handling [10]. It is reported that mercury is poorly recovered in ASGM processes and the emission factor can be as high as $15 \mathrm{~g}$ of mercury per gram of gold recovered [11]. Thus, ASGM is inextricably linked with human health, social, environmental and economic problems [9].

110 Elemental mercury intoxication causes irreversible neurological, kidney and autoimmune impairment accompanied by respiratory tract irritation, chemical pneumonitis, pulmonary 112 oedema, chest tightness, respiratory distress [12], respiratory failure and subsequently death [13]. 113 Systemic absorption of elemental mercury causes nausea, vomiting, headache, fever, chills, 114 abdominal cramps and diarrhea. Chronic, lower level exposure to elemental mercury induces 115 gingivostomatitis, photophobia, tremors and neuropsychiatric symptoms [14]. Elemental and 116 inorganic mercury toxicity in children may be witnessed in oedematous, painful, red, 117 desquamating fingers and toes (acrodynia) as well as hypertension [15]. 
118

119

120

121

122

123

124

125

126

127

128

129

130

131

132

133

134

135

136

137

138

139

140

141

142

143

144

145

146

147

148

149

150

151

152

153

154

155

156

157

Mercury used in recovering gold by artisanal miners may get transmogrified along the food chain into methyl mercury which is the most toxic organic form of mercury that can bioaccumulate in the food chain $[15,16]$. Methyl mercury because of its lipid-solubility readily enter the bloodstream via the digestive system [17]. On crossing the blood-brain barrier, methyl mercury accumulate in the spinal cord, triggering headache, ataxia, dysarthria, visual field constriction, blindness, hearing impairment, psychiatric disturbance, muscle tremor, movement disorders, paralysis and death [18].

Uganda National Environmental Management Authority reported in 2017 that the Ugandan ASGM sector contribute an estimated annual mercury input of 18.495 tons, of which 12.136 tons are released in the air, 3.333 tons are released in water and 3.027 tons are disposed on land [19]. As reported in other ASGM areas globally, wastes containing residual mercury from ASGM are often discharged in a perverted fashion into fragile ecosystems [20, 21], causing prodigious pollution of water, sediments, biota, soil and air [22-24]. This is disastrous for the case of Syanyonja and Busia as a whole since the mercury can get entrained in sediments which are carried to "the life artery of East African countries" (Lake Victoria), located $30 \mathrm{~km}$ downstream [3].

This study provide the first ever comprehensive assessment of the mercury contamination of water, sediment, fish and yams from Namukombe stream in Syanyonja village, Busia gold district, Uganda and create a paradigm for future studies aimed at developing strategies for reducing mercury pollution from ASGM in Busia. The results of this study is also a resource to Uganda National Environmental Management Authority and Ministry of Energy and Mineral Development.

\section{Materials and Methods}

\section{Description of study area}

Busia gold district is located between $33^{\circ} 05^{\prime} \mathrm{E} 00^{\circ} 10^{\prime} \mathrm{N}$ and $34^{\circ} 01^{\prime} \mathrm{E} 00^{\circ} 35^{\prime} \mathrm{N}$. It covers 730.9 square kilometres of land and is bordered by Tororo district to the North, Kenya to the East, Lake Victoria to the South, Namayingo district to the Southwest and Bugiri district to the west. Available land area is 648.95 square kilometres while open water and swamps cover about 36.88 square kilometres [10]. It has $10 \mathrm{sub}$ counties, 58 parishes and 609 villages characterized by undulating plain topography with an altitude of 1128 meters above sea level at Nebolola hills in Lumino sub county. Low lying areas (valleys) lie at altitudes of 1,000 meters above sea level with River Malaba valley to the north and River Lumboka to the west (Figure 1). The landscape is comprised of a mixture of auriferous hard rock (70\%) and 30\% alluvial soil [10].

Busia experience a bimodal rainfall pattern with an average annual rainfall of $1727 \mathrm{~mm}$. The first dry rainy season (short rains) start from March to May, followed by a longer rainy season between August to November. This climatological characteristic facilitates the leaching of poorly managed mercury wastes from ASGM sites into water bodies in the surrounding areas [10].

Busia is characterized by two distinct hydrographical networks (Figure 1). There is a northern network with River Malaba, River Kibimba and River Kitambogo draining into Lake Kyoga and 
158 a southern network with rivers: Sio, Nasigombe, Nalioba, Namagenge, Nalwire and Namatu 159 draining into Lake Victoria [25]. All the streams in the study area (such as Solo, Namukombe, 160 Dad, Okame, Nakola, Tira and Osapiri) are tributaries of River Malaba.

161 The current study was conducted in Namukombe stream in Syanyonja village, Samia Bugwe 162 constituency, Busitema sub county (00 $0^{\circ} 4^{\prime} 21^{\prime}$ 'N 34 $03^{\prime} 00^{\prime \prime}$ E), Busia gold district, South East of 163 the Republic of Uganda. Syanyonja village lies in the coordinates UTM 60648 36N617118 [26]. 164 Namukombe stream, a tributary of River Malaba, is one of the major water bodies in Syanyonja 165 village where mercury-based ASGM activities and fishing are done (Figure 2). Water for 166 drinking and domestic use are collected from the stream because the community have few 167 boreholes and permanent wells as alternative water sources. Growing of food crops (millet, 168 cassava, rice, sweet potatoes, yams, simsim, sorghum, cow peas and bananas) [27] are done along the banks of the stream. The most important activities in Busia are fishing and the crossborder trade [28]. A significant portion of the population engage in artisanal mining and panning of soil and stream sediments for gold [27].

172

Thus, the selection of the study area was based on the fact that the stream receives drainage from three artisanal mercury-based gold recovering sites (1, 2 and 3; Figure 3) located approximately $800 \mathrm{~m}$ from each other and designated as up sluice, middle sluice and down sluice respectively (Figure 4). Wastewater from these gold recovery sites are discharged directly into the stream.

\section{Ethical approval}

This research required no ethical approval. However, field experiments were approved by Department of Mining and Water Resources Engineering, Faculty of Engineering, Busitema University, Tororo, Busitema, Uganda for Shakilah Karungi (Approval No. BU/UG/2013/95)

\section{Collection and preparation of samples}

183

184

185

186

187

188

189

190

191

192

193

194

195

196

Water and sediments were selected to determine the concentration of mercury being released into the stream with wastewater. Fish and yams were selected in this study because they constitute the daily diet of the local community. Some miners eat smoked fish without boiling.

Samples were obtained in triplicate from up, middle and down sluices at $0 \mathrm{~m}, 10 \mathrm{~m}, 20 \mathrm{~m}$ and 30 $\mathrm{m}$. Fish and yam samples were obtained at most from within a radius of $5 \mathrm{~m}$ from the sampling points indicated in Figure 4.

Water samples were collected manually in $500 \mathrm{ml}$ Teflon plastic bottles. The bottles, previously cleaned by washing in non-ionic detergent, were rinsed with tap water, soaked in $10 \%$ nitric acid for 72 hours and finally rinsed with deionized water before use. Each bottle was rinsed 3 times with stream water at each sampling point, filled $20-25 \mathrm{~cm}$ below the water surface and capped with airtight stoppers while still under water. The samples were filtered through predried polyvinylidene difluoride membrane filters (Millipore, $0.45 \mu \mathrm{m}$ pore diameter) and preserved with $5 \mathrm{ml}$ of concentrated nitric acid to achieve $\mathrm{pH}<2.0$ (to minimize precipitation and sorption losses to the bottle walls). 
222

223

224

225

226

227

228

229

230

231

232

233

Superficial sediment samples were obtained using a grab sampler at 0-5 cm in accordance with the United Nations Environment Programme's reference method for sediment pollution studies (UNEP method number RSRM 20) [29] to preclude contamination and address geographic differences. Sediment samples collected were put in clean presterilized plastic polypropylene bottles, tightly sealed and labelled. The samples were oven-dried at $80-95^{\circ} \mathrm{C}$ for 16 hours until a constant weight was attained. They were subsequently crushed in a stone mortar and sieved through a $0.63 \mu \mathrm{m}$ nylon mesh sieve. Particle size fraction of $<63 \mu \mathrm{m}$ for analysis is recommended as it is the most near to be taken as equivalent to materials carried in suspension [30]. The powdered sediment samples were preserved at $4{ }^{\circ} \mathrm{C}$ on an ice block.

Fish samples (5.5 to $8.0 \mathrm{~cm}$ fork length) were caught using hooks fed with earthworms as baits. The samples were preliminarily prepared for analysis as described by Omara et al. [31].

Yam tubers obtained were manually peeled using a stainless-steel knife and cut into small pieces. Aliquots $(3.0 \pm 0.1 \mathrm{~g})$ were weighed and ashed in a furnace at $550{ }^{\circ} \mathrm{C}$ for 5 hours.

\section{Analytical reagents and apparatus used}

Standard mercury solution was purchased from Sigma Aldrich (Steinheim, Swiss). The other reagents, except certified reference materials, were obtained from Merck (Darmstadt, Germany). Water used as solvent was deionized water.

The assortment of volumetric ware used were soaked overnight in $10 \%(\mathrm{v} / \mathrm{v})$ nitric acid solution, rinsed with deionized water [32] and oven dried prior to analysis.

Mettler PM200 digital analytical balance (Marshall scientific, USA) was used for all analytical weighing. Hanna 211 digital microprocessor-based bench top $\mathrm{pH} / \mathrm{mV} /{ }^{\circ} \mathrm{C}$ meter (Hanna instruments, Italy) calibrated using $\mathrm{pH} 4.01,7.01,10$ buffers was used for all $\mathrm{pH}$ measurements.

\section{Spectroanalytical procedure}

\section{Water samples}

The concentration of total dissolved mercury $(\mathrm{THg})$ in water samples $(5 \mathrm{ml}$ aliquots) were determined using cold vapour atomic fluorescence spectrometer (CV-AFS Brooks Rand® Model III, Brooks Rand Instruments, USA) in accordance with US EPA method 1631 [33], modified for measurement of low-level mercury in water [34].

Briefly, $50 \mathrm{ml}$ of the samples were subjected to bromination using $0.2 \mathrm{~N}$ bromine monochloride in a ratio of $1: 2 \%(\mathrm{v} / \mathrm{v})$ to break down any organomercury compounds in the samples to mercury (II) ions. The samples were kept in an oven at $50{ }^{\circ} \mathrm{C}$ for 12 hours. Prior to analysis, excess bromine (as shown by presence of yellow tints) in the samples was neutralized with $10 \%$ hydroxylamine hydrochloride. After 10 minutes, the samples were then reduced with 5 $\mathrm{ml}$ of stannous chloride. Measured $5 \mathrm{ml}$ aliquots of the resultant solution were purged with 
234 mercury-free nitrogen gas for 20 minutes and trapped on columns packed with gold coated sand. 235 The gold trap was heated, and the desorbed mercury detected with Cold-Vapor Atomic 236 Fluorescence Spectrophotometer following manufacturer's conditions with a practical detection 237 limit of $0.001 \mathrm{mg} / \mathrm{L}$.

238

239

240

241

242

243

244

245

246

247

248

249

250

251

252

253

254

255

256

257

258

259

260

261

262

263

264

265

266

267

268

269

270

271

272

273

\section{Sediment, fish and yam samples}

Digestion of sediment, fish and yam samples were performed using a procedure modified from USEPA method 1631 Appendix for digested (oxidized) solid samples [35] to allow for THg determination using the manual 245.7 system coupled to a ball flowmeter and a multi-channel pump as per cold vapour atomic fluorescence spectrometer (Brooks Rand ${ }^{\circledR}$ Model III, Brooks Rand Instruments, USA) manufacturer's instructions [36]. This system is supplied with Brooks Rand Guru ${ }^{\mathrm{TM}}$ software for system control and peak integration.

For each sample, three separate aliquots $(0.25 \mathrm{~g})$ were transferred to $50 \mathrm{ml}$ polypropylene test tubes. To the aliquots, $5 \mathrm{ml}$ of $3: 1(\mathrm{w} / \mathrm{w})$ sulphuric acid : nitric acid mixture were added and allowed to stand at room temperature $\left(25^{\circ} \mathrm{C}\right)$ for 2 hours. The samples were heated to $80^{\circ} \mathrm{C}$ for 40 minutes and subsequently liquefied. $15 \mathrm{ml}$ of $6 \mathrm{~N}$ hydrochloric acid, $3 \mathrm{ml}$ of $0.1 \mathrm{~N}$ bromine monochloride solution and $4 \mathrm{ml}$ of deionized water were added. The samples were agitated and then heated to $60{ }^{\circ} \mathrm{C}$ for 1 hour. Fish samples turned yellow in color, with the resultant solutions remaining clear without any precipitate. Each sample was diluted in a ratio of $1: 10$ with $2 \%$ (w/v) hydrochloric acid. Exactly $0.1 \mathrm{ml}$ of $10 \%$ hydroxylamine hydrochloride solution was added to remove excess bromine. The samples ( $5 \mathrm{ml}$ aliquots) were then analyzed for THg using Brooks Rand ${ }^{\circledR}$ Model III cold vapour atomic fluorescence spectrometer using the manual 245.7 system following the manufacturer's instructions. This semi-automated instrument allowed simultaneous purging of multiple samples while previously loaded amalgamation traps were analyzed with a throughput rate of less than 5 minutes per sample.

The THg concentrations were reported in $\mathrm{mg} / \mathrm{L}$ for water or $\mu_{\mathrm{gg}}{ }^{-1} \mathrm{dry}$ weight for solid matrices for easy comparison with set international compliance limits.

\section{Analytical quality assurance and quality control}

All reagents used in this investigation were of high analytical purity. Quality control was performed with certified reference materials and spiked samples analyzed once for every 10 samples. Certified reference materials for water (NRCCORMS-5, National Research council Canada, USA), sediment (CRM008-050, Resource Technology Corporation, USA) and fish (SRM 2976, National Institute of Standards and Technology, USA) were used to assess recovery which yielded respectively $99.6 \%, 102.8 \%$ and $101 \%$ of the certified mercury values (Supplementary table, S1). Mercury recovery percentages from the spiked samples were $98.8 \%, 98.2 \%, 97.9 \%$ and $99.2 \%$ for water, sediment, fish and yam samples respectively. All samples were analyzed at least in triplicate to obtain a relative uncertainty of less than $5 \%$. In other words, precision in the analysis was in good agreement, better than $\pm 5.0 \%$ relative standard deviation. 
274

275

276

277

278

279

280

281

282

283

284

285

286

287

288

289

290

291

292

293

294

295

296

297

298

299

300

301

302

303

304

305

306

Method detection limit with reagent blanks was calculated and used as a verification tool. The calculated method detection limits were $0.001 \mathrm{mg} / \mathrm{L}$ for water and $0.001 \mu \mathrm{gg}^{-1}$ for the solid matrices. Bottle, analytical, equipment and filtration blanks were determined throughout the analyses, and blank subtractions were used to correct the mercury concentrations obtained.

\section{Human health risk assessment}

Estimated daily intake (EDI) was calculated to averagely estimate the daily mercury loading into the body system of a specified body weight of a consumer (adult/child) through consumption of contaminated fish and yams while the average daily dose $\left(\mathrm{ADD}_{\text {therm }}\right)$ was calculated to determine intoxication through skin contact with mercury-contaminated sediments. These provide the relative availability of mercury but does not take into cognizance the possibility of metabolic ejection of mercury. EDI in $\mu \mathrm{gg}^{-1} \mathrm{day}^{-1}$ was calculated using Equation 1 previously employed elsewhere [31] while $\mathrm{ADD}_{\text {therm }}\left(\mu \mathrm{gg}^{-1} \mathrm{day}^{-1}\right)$ was calculated from Equation 2 [37-39].

$$
\begin{aligned}
& \mathrm{EDI}=\frac{E_{f} \times E_{d} \times F_{i r} \times C_{f} \times C_{h m}}{W_{a b} \times T_{a e t}} \\
& \mathrm{ADD}_{\text {therm }}=\frac{C_{h m} \times S_{A} \times A F \times E_{f} \times E_{d}}{W_{a b} \times T_{a e t}} \times 10^{-6}
\end{aligned}
$$

Where $E_{f}=$ exposure frequency (365 days/year), $E_{d}=$ exposure duration, the average lifetime (58.65 years for an adult Ugandan) [40], $F_{\text {ir }}$ is the fresh food ingestion rate (g/person/day) $=48$ for fish and 301.0 and 231.5 for yams eaten by adults and children respectively) [41, 42], $C_{\mathrm{f}}$ is the conversion factor $(0.208)$ for fresh weight $\left(F_{\mathrm{w}}\right)$ to dry weight $\left(D_{\mathrm{w}}\right)$ for fish and 0.085 for yams (considering it as a vegetable) [43], $C_{\mathrm{hm}}=$ heavy metal concentration in the foodstuffs $\left(\mu g^{-1} F_{\mathrm{W}}\right), W_{a b}=$ average body weight (considered to be $15 \mathrm{~kg}$ for children [39] and $60 \mathrm{~kg}$ for adults [44]), $T_{\text {aet }}=$ average exposure time for non-carcinogens (given by the product of $E_{\mathrm{d}}$ and $E_{\mathrm{f}}$ ) [45], $\mathrm{S}_{\mathrm{A}}$ is the exposed surface area in $\mathrm{cm}^{2}=4,350$ for adults and 2,800 for children [39], $\mathrm{AF}$ is the skin adherence factor in $\mathrm{mg} / \mathrm{cm}^{2} / \mathrm{day}=0.7$ for adults [46] and 0.2 for children [39].

Health risk index, the total risk of a non-carcinogenic element through three exposure pathways was evaluated using Target hazard quotient in accordance with US EPA region III riskbased concentration table [47] used in a preceding study [31]. According to the criterion, target hazard quotient less than unity (1.0) indicate that the exposure is very unlikely to have adverse effects while target hazard quotient greater than 1.0 represent a possibility of non-carcinogenic effects, with its probability increasing as the value of the target hazard quotient increases [31]. Target hazard quotient was calculated as the ratio of EDI or $\mathrm{ADD}_{\text {therm }}$ to the reference dose $\left(\mathrm{R}_{f} \mathrm{D}\right)$ (Equation 3) [31, 38].

$$
\text { Target hazard quotient }=\frac{E D I}{R_{f} D} \text { or Target hazard quotient }=\frac{A D D_{\text {therm }}}{R_{f} D}
$$


308 The reference dose of mercury through ingestion in $\mu \mathrm{gg}^{-1} \mathrm{day}^{-1}$ is $4.0 \times 10^{-1}$ [41] while the

309

310

311

312

313

314

315

316

317

318

319

320

321

322

323

324

325

326

327

328

329

330

331

332

333

334

335

336

337

338

339

340

341

342

343

344

345

346

347

reference dose for mercury through skin contact is $1.0 \times 10^{-2} \mu_{g^{-1}} \mathrm{day}^{-1}$ [39].

The reference dose is the maximum daily dose of a metal from a specific exposure pathway, that is believed not to lead to an appreciable risk of deleterious effects to sensitive individuals during a life time [48]. If the EDI is lower than the reference dose, the target hazard quotient is less than 1 and adverse health effects are unlikely to appear, whereas if the EDI exceed the reference dose, target hazard quotient is greater than 1 and adverse health effects are likely to appear $[37,38]$. In this study, the target hazard quotient was calculated basing on three pathways i.e. consumption of mercury-contaminated fish and yams and skin contact with mercury (miners come into contact with dredged mercury-contaminated sediments during panning).

The assumptions made during the health risk calculations were that the ingested dose is equal to the dose absorbed into the body [49] and cooking of fish and yams have no effect on the mercury content of the assessed matrices [50].

\section{Assessment of bioaccumulation factors}

Bioaccumulation factors are multipliers used to estimate concentration of chemicals that accumulate in tissues through any route of exposure [51]. They are often referred to as bioconcentration factors for aquatic invertebrates. The bioconcentration factors and biota to sediment accumulation factor of trace metals from sediment or surface water to animal tissues can be determined for different samples. Thus, bioconcentration factor was determined from the numerical ratio of the concentration of mercury in the whole edible tissues of $O$. nilotica to concentration of mercury in water while biota to sediment accumulation factor was determined from the ratio of the concentration of mercury in the edible muscles of $O$. nilotica to that of mercury in the corresponding sediment samples [52].

\section{Sediment quality assessment}

To assess the level of contamination as well as the environmental and health risks that originate from a heavy metal's occurrence, indices are used to indicate the enrichment of a given environmental component as compared to its natural concentration. The indices used to describe heavy metal enrichment of sediments include contamination factor, enrichment factor, pollution load index, geoaccumulation index, potential ecological risk and hazard quotient [53-55].

These indices are used as a rule at thumb to subtly assess sediment contamination. However, these do not allow comparison of the degrees of contamination of sediments investigated in different studies. To identify pollution problems, the anthropogenic contributions should be distinguished exclusively from the natural sources. Thus, the degree of mercuric contamination of sediments from Namukombe stream was assessed using contamination factor and geoaccumulation index.

The contamination factor was calculated using Equation 4 given by Hakanson [53].

$$
\text { Contamination factor }=\frac{C_{h m}}{C_{b}}
$$


348

349

350

351

352

353

354

355

356

357

358

359

360

361

362

363

364

365

366

367

368

369

370

371

372

373

374

375

376

377

378

379

380

381

382

383

384

385

386

where $\mathrm{C}_{\mathrm{hm}}$ is the priority trace metal concentration in the analyzed sample and $\mathrm{C}_{\mathrm{b}}$ is the geochemical background trace metal concentration/preindustrial concentration. A background concentration of $0.25 \mu \mathrm{gg}^{-1}$ of mercury in crustal shale was adopted from Taylor [56].

Geoaccumulation index $\left(\mathrm{I}_{\mathrm{geo}}\right)$ for the sediments from the different sluices were obtained from computations utilizing Equation 5 suggested by Müller [57].

$$
\mathrm{I}_{\text {geo }}=\log _{2}\left(\frac{C_{n}}{1.5 B_{n}}\right)
$$

where $C_{n}$ is the concentration of the trace metal $(n)$ in the sampled and analyzed sediment, $\mathrm{B}_{\mathrm{n}}$ is the background concentration of the same metal and 1.5 is the background matrix correction factor due to lithogenic effects (takes into account possible lithological variability) [58, 59].

\section{Statistical analysis of results}

Analytical data were checked for normality prior to statistical evaluation using KolmogorovSmirnov (K-S) test. In case of acceptance, differences among concentrations of THg in water, sediment, fish and yam samples were determined using one-way analysis of variance (ANOVA). Kruskal-Wallis test was applied when data did not follow a normal distribution and previous transformation did not normalize them. To identify the source of significant differences between groups, Tukey pairwise and Dunn's multiple comparison tests were done for parametric and nonparametric data respectively. These statistical analyses were performed at a $95 \%$ confidence interval (with differences in mean values accepted as being significant at $p<0.05$ ) using Sigma Plot statistical software (v 14.0, Systat Software Inc., San Jose, CA, USA).

\section{Results and Discussion}

The mercury content of water, sediments, fish and yams from the different sluices of Namukombe stream with their descriptive statistics are given in Table 1.

\section{Water}

Mean total mercury content of the water samples ranged from $<$ detection limit to $1.21 \pm 0.040$ $\mathrm{mg} / \mathrm{L}$. Total mercury in water samples from up sluice were initially high at $0 \mathrm{~m}$ but reduced drastically after a distance of $10 \mathrm{~m}$ from the gold recovering site. There was a gradual decrease from $1.21 \pm 0.040$ to $0.09 \pm 0.001 \mathrm{mg} / \mathrm{L}$ up sluice, $0.18 \pm 0.070$ to $0.02 \pm 0.01 \mathrm{mg} / \mathrm{L}$ in middle sluice and $0.10 \pm 0.030 \mathrm{mg} / \mathrm{L}$ until no detection down sluice (Table 1).

The observed decrement could be due to the fact that Namukombe stream is swampy, thus the flow of water is reasonably slow. Namukombe stream is rich in organic matter, thus some of the mercury might have been retained within the sediments. It is reported that organic matter can increase mercury methylation by stimulating heterotrophic bacteria (Pseudomonas species) in aerobic condition or by abiotic methylation $[60,61]$. In anaerobic condition, mercury react with organic carbon in the sediments to form toxic methyl and di-methyl mercury [61]. Some anaerobic bacteria that possess methane synthetase are also reported to be capable of mercury methylation [62]. 
387

388

389

390

391

392

393

394

395

396

397

398

399

400

401

402

403

404

405

406

407

408

409

410

411

412

413

414

415

416

417

418

419

420

421

422

423

424

425

426

Further, owing to their static nature, sediments tend to get enriched with toxic materials more than water, which can undergo relatively rapid self-purification. Thus, a greater percentage of $\mathrm{THg}$ in an aquatic system is expected in sediments if there is effective binding with organic carbon bearing particles. This may innocuously retard the transfer of $\mathrm{Hg}$ to overlying water through interstitial water [63].

Heavy metals which are less soluble in water such as $\mathrm{Hg}$ are easily adsorbed and accumulated in sediments [64]. However, in the event that the trace metal cannot be permanently adsorbed by sediments, it is released back to the overlying water when environmental conditions such as salinity, resuspension, $\mathrm{pH}$, redox potential and organic matter decay rate changes [65, 66]. High (alkaline) $\mathrm{pH}$ and a decrease in chloride ion content for example enhances the mobility of mercury in aquatic environment, thereby favoring adsorption of mercury with oxides of iron, aluminium and silicon [67] as well as clay. Abiotic inorganic mercury have also been reported to reduce in the presence of electron donors and low redox potentials [68]. Lino et al. [69] reported that suspended particles are the main carrier of mercury in water column and sediments. More so, biotic and abiotic factors seem to interact in a complex way in an aquatic ecosystem, causing marked variations in mercury concentrations in matrices [69]. These explain the low levels of mercury reported in sediments than in water.

The levels of THg reported in water by this study is comparable to that of Oladipo et al. [70] and Mahre et al. [71] (Table 2). Further, mercury content of water in this study is concordant with preceding investigations which concluded that the quality of water in the periphery of mercury-based ASGM sites in Uganda have been deteriorated by mercury pollution [72, 73].

All the THg concentrations of the water samples except one (8.3\%) sample from $30 \mathrm{~m}$ down sluice in this study were higher than the US EPA maximum contamination level of $0.002 \mathrm{mg} / \mathrm{L}$ for mercury in drinking water. Therefore, $91.7 \%$ of water sampled in this study is not safe for drinking.

\section{Superficial sediments}

Sediments are good hosts of highly toxic pollutants from natural and anthropogenic sources [74] and have been reported as the biggest sink and major reservoir for heavy metals [75-82]. Sediments enhance accumulation of heavy metals in benthic invertebrates, thereby transferring them to higher levels of the food chain [83-87]. Therefore, monitoring sediments can give better understanding of trace metal contamination of aquatic ecosystems [88-94] compared to water and/or floating aquatic plants which tend to give inaccurate estimations due to water discharge fluctuations and lower resident times.

Mean THg concentrations of sediments from up sluice ranged from $<$ detection limit to $0.14 \pm$ $0.040 \mu \mathrm{gg}^{-1}$ while in the middle sluice, THg content of sediments ranged from $<$ detection limit to $0.11 \pm 0.061 \mu \mathrm{gg}^{-1}$. Down sluice, $\mathrm{THg}$ content of sediments ranged from $<$ detection limit to $0.12 \pm 0.01 \mu^{\prime g}{ }^{-1}$ (Table 1). All the mean THg concentrations of the sediments from the three sluices were lower than the maximum permissible limit of $0.15 \mu \mathrm{gg}^{-1}$ recommended by USEPA 2001 standard [33]. For all the sluices, THg concentration in the sediments reduced with distance 
427 (Table 1) from the point source of pollution. No mercury was detected in sediments sampled 30 $428 \mathrm{~m}$ away from all the gold recovery sites.

429 The mean THg content of the sediments in this study is lower than the values registered in 430 other global studies such as that reported by Donkor et al. [95], Ramirez-Requelme et al. [96] 431 and Feng et al. [97] (Table 2). However, Mohan et al. [61], Oladipo et al. [70], Lasut et al. [98], 432 Pataranawata et al. [99] and Taylor et al. [100] reported lower $\mathrm{THg}$ content of sediments

433

434

435

436

437

438

439

440

441

442

443

444

445

446

447

448

449

450

451

452

453

454

455

456

457

458

459

460

461

462

463

464

465 comparable to the THg concentrations recorded in this study (Table 2).

$\mathrm{THg}$ content of all the sediment samples except one i.e. sample from $0 \mathrm{~m}$ up sluice $(0.14 \pm$ $0.040 \mu \mathrm{gg}^{-1}$ ) were below Threshold Effect Level (TEL) of $0.13 \mu \mathrm{gg}^{-1}$. All the $\mathrm{THg}$ concentrations of the sediments were lower than the Probable Effect Level (PEL) of $0.70 \mu g^{-1}$ for $\mathrm{Hg}$ in sediments postulated by Smith et al. [101] and MacDonald [102]. THg in the sediments lying between TEL and PEL is expected to be associated with adverse biological effects [61]. Also, among the bottom sediment samples, none had mean THg higher than the

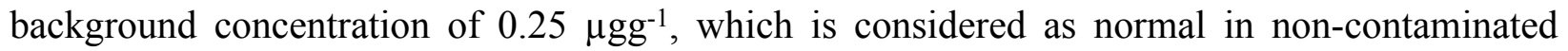
sediments [103]. It is worth noting that the mercury content of the sediments in this stream were lower than the $\mathrm{THg}$ content of water from the corresponding sluices.

In this study, the retention rates of $\mathrm{Hg}$ in sediments, which is influenced by many factors such as the metallic forms of mercury (i.e. elemental, ionic, organic, or inorganic), $\mathrm{pH}$, temperature, organic carbon and electrical conductivity were not investigated. Because the sediment $\mathrm{Hg}$ retention rates can vary from one location to another, the observed variability in $\mathrm{THg}$ concentrations in sediments from the sluices can be attributed to the differences in the sediment $\mathrm{Hg}$ retention rates, the distance from the source of the pollutant and the level of pollution from ASGM activities by the gold recovering sites. According to the Sediment Quality Criteria for Protection of Aquatic Life (Environment Canada, 1992 cited in [104]), all the sediments in this study had mean $\mathrm{THg}$ below the toxic threshold of $1.0 \mu \mathrm{gg}^{-1}$ and minimal effects threshold of 0.20 $\mu \mathrm{gg}^{-1}$.

\section{Oreochromis nilotica}

Fish from all the sluices had mean THg in the range of $<$ detection limit to $0.11 \pm 0.014 \mu g^{-1}$ (Table 1). The mean THg content of all the fish samples from the stream did not exceed the maximum WHO permissible limit for mercury in fish for human consumption $\left(0.50 \mu g^{-1}\right)$ as well as the WHO recommended limit for vulnerable groups $\left(0.20 \mu \mathrm{gg}^{-1}\right)$.

The highest mean $\mathrm{THg}$ content of fish reported in this study is lower than the mean $\mathrm{THg}$ reported by Castilhos et al. [105] (Table 2). Oladipo et al. [70] and Mahre et al. [71] reported THg content of edible fish muscles lower than is reported in O. nilotica tissues by the current study (Table 2).

In this investigation, fish samples obtained from areas close to the gold recovery sites had higher THg content than those obtained from sampling points far from the gold recovery sites (Table 1). This could be due to a reduction in the mercury content of water as it spreads from the 
466

467

468

469

470

471

472

473

474

475

476

477

478

479

480

481

482

483

484

485

486

487

488

489

490

491

492

493

494

495

496

497

498

499

500

501

502

503

504

505

source of pollution. Mercury could have probably got entrained in the sediments as it spread outwards.

It is reported that fish ingest heavy metals by direct uptake in aqueous solution or by epithelial absorption of heavy metal contaminated water that sluices through their gills, skin, oral cavity and digestive tract [106]. However, chronic intake of heavy metals by fish rest entirely on the metal concentration, volume of the ingested contaminated food or water, the heavy metal uptake speed, exposure duration, uptake route, ecological conditions external to the fish (including availability of water, temperature, $\mathrm{pH}$ ) and innate factors such as fish age [107], fish nutritional habits as well as the dynamic processes involved in the trace metal metabolism when ingested [108]. Therefore, the lower levels of $\mathrm{Hg}$ recorded in this study could be because the fish samples were not so aged and the fact that $O$. nilotica is non-piscivorous. This is corroborated by the reports of Mol et al. [109] who reported that the THg concentrations in freshwater piscivorous fish species in ASGM areas of Suriname, South America was $0.71 \mu \mathrm{gg}^{-1}$, about 3.7 times higher than $0.19 \mu \mathrm{gg}^{-1}$ recorded in non-piscivorous species in the same mercury-contaminated water bodies. Marrugo-Negrete et al. [110] reported a similar finding in which carnivorous fish species: Caquetaia kraussi, Hoplias malabaricus and Plagioscion surinamensis in an aquatic system impacted by gold mining in Northern Colombia had high mean $\mathrm{THg}$ concentrations of $1.09 \pm 0.17,0.58 \pm 0.05$ and $0.53 \pm 0.07 \mu \mathrm{gg}^{-1}$ fresh weight respectively while the lowest $\mathrm{THg}$ $\left(0.157 \pm 0.01 \mathrm{Hgg}^{-1}\right.$ fresh weight $)$ was reported in a non-carnivorous fish species, Prochilodus magdalenae.

Weber et al. [111] reported that aquatic organisms exposed to copious levels of waterborne trace metals bioconcentrate the metals upon absorption, ultimately transferring them to humans as they are inevitable in human nutrition. Thus, for the general population, dietary intake is the dominant exposure pathway to mercury. Though the levels of THg in the edible muscles of $O$. nilotica consumed by the local community of Syanyonja village registered in this study are evidently low, the effect of mercury accumulation should not be overruled as other metabolically active organs such as the gills, liver and kidneys might contain higher THg concentrations [31]. Dietary exposure to mercury has been proven to cause elevated risks of cardiovascular diseases with severe exposure negatively impacting the reproductive and immune systems $[112,113]$.

\section{Dioscorea alata}

The mean THg content of yams (D. alata) from Namukombe stream varied between $<$ detection

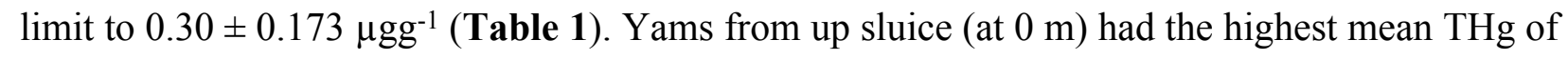
$0.30 \pm 0.173 \mu \mathrm{gg}^{-1}$. Middle sluice samples at $0 \mathrm{~m} \mathrm{had} \mathrm{THg}$ content of $0.28 \pm 0.026 \mu \mathrm{gg}^{-1}$, while down sluice samples at $0 \mathrm{~m}$ had the highest mean THg content of $0.29 \pm 0.066 \mu \mathrm{gg}^{-1}$ (Table 1). There was no appreciable difference in the THg content of the yams from the different sluices. This trend can be related to the levels of $\mathrm{Hg}$ in both water and sediments from the sluices in relation to the distance of the samples from the ASGM activities. The highest mean $\mathrm{THg}$ content of yams grown in Namukombe stream is quite higher than that reported by Taylor et al. [100] (Table 2). It is worth noting that yams in this stream recorded the highest $\mathrm{THg}(0.30 \pm 0.173$ 
$\left.506 \mu \mathrm{gg}^{-1}\right)$ of all the studied matrices. This could be because yams are exposed to diverse routes of 507 contamination by mercury from ASGM activities such as the sediments (soils), contaminated 508 water and atmospheric disposition on leaves during growth. However, the mean THg content of 509 yams reported could probably be higher than recorded due to losses during ashing at $550{ }^{\circ} \mathrm{C}$ for 5 510 hours.

511 Overall, the results of this study are concordant with other global studies which observed 512 elevated $\mathrm{THg}$ concentrations in water and sediments, with patterns of decreasing $\mathrm{THg}$ 513 concentration with distance from ASGM sources [114-116].

514

515 Health risk assessment from consumption of fish and yams and skin contact with sediments 516 from Namukombe stream

517 Chronic low level intake of priority trace metals such as mercury have been implicated for 518 deleterious human health effects, which become apparent following years of persistent exposure

519

520

521

522

523

524

525

526

527

528

529

530

531

532

533

534

535

536

537

538

539

540

541

542

543

544 [117-119]. Target hazard quotient method was used to assess the potential health risks of $\mathrm{Hg}$ accumulation through consumption of the edible muscles of $O$. nilotica and D. alata as well as dermal contact during ASGM.

The estimated daily intakes (EDIs) ranged from 0.0049 to $0.0183 \mu \mathrm{gg}^{-1} \mathrm{day}^{-1}$ and 0.020 to 0.073 $\mu \mathrm{gg}^{-1} \mathrm{day}^{-1}$ for fish consumed by adults and children respectively. The corresponding health risk indices (HRIs) ranged from 0.0123 to 0.0458 and 0.05 to 0.183 (Table 3, Table 4). In 1960s, Minamata residents of Japan suffered unprecedented neuropathies due to consumption of mercury-contaminated seafood [120]. More so, some studies have reported that mercury is toxic to fish (Tilapia guineersis and Tilapia fuscatus) and induce fish weight loss even on exposure to sub-lethal doses of mercury in more than two fortnights [121]. Thus, O. nilotica in Namukombe stream is endangered due to the detected mercury pollution of the fish.

The EDIs were from 0.0042 to $0.1279 \mu \mathrm{gg}^{-1} \mathrm{day}^{-1}$ and 0.013 to $0.394 \mu \mathrm{gg}^{-1} \mathrm{day}^{-1}$ for yams consumed by adults and children respectively. The statistical HRIs recorded were from 0.011 to 0.320 and to 0.033 to 0.985 respectively (Table 3, Table 4). The HRI of 0.985 registered for consumption of yams from $0 \mathrm{~m}$ up sluice by children is very close to 1.0, implying that consumption of yams from this site by children might lead to mercury-related health risks.

The $\mathrm{ADD}_{\text {therm }}$ ranged from $1.015 \times 10^{-6}$ to $7.105 \times 10^{-6} \mu \mathrm{gg}^{-1} \mathrm{day}^{-1}$ and $7.47 \times 10^{-7}$ to $5.227 \times 10^{-6} \mu \mathrm{gg}^{-1} \mathrm{day}^{-1}$ (Table 3, Table 4) for contact with mercury-contaminated dredged sediments from Namukombe stream by adults and children respectively. The HRIs respectively ranged from $1.015 \times 10^{-4}$ to $7.105 \times 10^{-4}$ and $7.47 \times 10^{-5}$ to $5.227 \times 10^{-4}$ for adults and children (Table 3, Table 4).

Target hazard quotient of less than unity (1.0) indicate the relative absence of health risks associated with intake of $\mathrm{Hg}$ through consumption of either mercury contaminated fish, yams or contact with sediments. However, ingestion of both fish and yams, coupled with persistent dermal exposure to mercury in sediments during panning would lead to potential health risks especially for children. 


\section{Mercuric accumulation based on bioaccumulation factors}

547 The bioaccumulation factors: bioconcentration factor and biota to sediment accumulation factor 548 computed for $O$. nilotica in Namukombe stream are presented in Table 5. The results show that 549 there are higher mercury levels in $O$. nilotica tissues than in the surface water samples. 550 Bioconcentration factors for mercury in $O$. nilotica were ranked as follows: down sluice $>$ 551 middle sluice $>$ up sluice. The highest bioconcentration factor of 0.800 was recorded at $0 \mathrm{~m}$ 552 down sluice while the lowest bioconcentration factor of 0.250 was recorded at $10 \mathrm{~m}$ middle 553 sluice. Such trace metal accumulation levels in fish as in this concerted study augment published 554 data reported by other authors on different species of aquatic organisms [52, 122-124]. 555 Therefore, this study suggests that $O$. nilotica is a sentinel organism for biomonitoring of aquatic 556 ecosystems.

557 Biota to sediment accumulation factor explored the rate of $\mathrm{Hg}$ uptake from sediments and its 558 subsequent accumulation in $O$. nilotica tissues. In this investigation, the highest biota to sediment 559 accumulation factor of 1.500 was recorded at $10 \mathrm{~m}$ in the middle sluice while the lowest biota to 560 sediment accumulation factor (0.333) was recorded at $10 \mathrm{~m}$ up sluice. Thus, mercury enrichment

561

562

563

564

565

566

567

568

569

570

571

572

573

\section{Geoaccumulation Index}

575

576

577

578

579

580

581

582

583 edible muscles of $O$. nilotica.

\section{Contamination factor} was highest in the middle sluice, though the sediments have higher concentrations of $\mathrm{Hg}$ than the

\section{Quality of superficial sediments from Namukombe stream}

All the statistical contamination factors were less than 1.0 (the highest statistical value of 0.56 was recorded at $0 \mathrm{~m}$ up sluice and the lowest value of 0.04 was reported at $10 \mathrm{~m}$ down sluice) (Table 5). According to Hakanson [53], four (4) contamination categories are distinguished: $<1$ : low contamination; $1 \leq$ factor $<3$ : moderate contamination, $3 \leq$ factor $<6$ : considerable contamination and factor $>6$ : very high contamination. Thus, basing on the criteria, there is very low contamination of sediments in the studied parts of Namukombe stream.

Müller geoaccumulation index $\left(\mathrm{I}_{\mathrm{geo}}\right)$ is a frequently employed analytical index for examination of the contamination level of sediment samples by trace metals. It assesses the degree of contamination by comparing the current levels of trace metal concentrations to the previous status of the research site. The computed Müller geoaccumulation indices for the bottom sediments from Namukombe stream ranged from -5.233 to -1.423 (Table 5).

The $I_{\text {geo }}$ is composed of seven grades along with associated sediment quality levels according to the degree of trace metal pollution. The values are classified as follows: no contamination $\left(\mathrm{I}_{\text {geo }}<0\right)$; low to median contamination $\left(\mathrm{I}_{\text {geo }}\right.$ between 0 and 1$)$; median contamination ( $\mathrm{I}_{\text {geo }}$ between 1 and 2 ); median to strong contamination $\left(\mathrm{I}_{\text {geo }}\right.$ between 2 and 3 ); serious contamination 
584 ( $I_{\text {geo }}$ between 3 and 4); serious to extreme contamination ( $I_{\text {geo }}$ between 4 and 5); and extreme 585 contamination $\left(\mathrm{I}_{\mathrm{geo}}>5\right)$.

586 In this study, the geoaccumulation indices were all negative for the sluices (Table 5), reflecting 587 that there is no serious anthropogenic pollution of the studied sluices in Namukombe stream.

588

\section{Conclusion and recommendations}

590 Persistent utilization of mercury in ASGM in Syanyonja and the proliferation of its

591

592

593

594

595

596

597

598

599

600

601

602

603

604

605

606

607

608

609

610

611

612

613

614

615

616

617

618

619

620

621

622

environmental and human health effects pose significant challenges to sustainability. Water in Namukombe stream is contaminated with up to $1.21 \pm 0.070 \mathrm{mg} / \mathrm{L}$ of $\mathrm{Hg}$ which is above US EPA maximum permissible limit for $\mathrm{Hg}$ in drinking water. The maximum $\mathrm{THg}$ content of sediments from the stream is $0.14 \pm 0.040 \mu \mathrm{gg}^{-1}$ which is lower than the maximum limit of 0.150 $\mu \mathrm{gg}^{-1}$ recommended by USEPA 2001 standard. Release of ASGM residual Hg into Namukombe stream have resulted in significant entrainment of $\mathrm{Hg}$ in water and sediments in the stream. The mercuric content of the edible whole muscles of the locally consumed fish (O. nilotica) is lower than in sediments, yams and drinking water.

THg content of the edible whole muscles of fish from Namukombe stream ranges from < detection limit to $0.11 \pm 0.010 \mu \mathrm{gg}^{-1}$ which is still within the maximum WHO permissible limit of $0.5 \mu \mathrm{gg}^{-1}$ for $\mathrm{Hg}$ in fish for human consumption. Health risk assessment indicate that consumption of $D$. alata from $0 \mathrm{~m}$ up sluice may have a potential health risk, particularly to children.

Further research should determine the geochemical properties $(\mathrm{pH}$, organic carbon and conductivity) of the sediments as these properties tend to correlate with limnologic mercury accumulation in sediments. Research should be done to evaluate the mercury content of metabolically active organs (gills, liver, kidney) of $O$. nilotica. The levels of methyl mercury and other trace metals such as Lead and Arsenic should be determined in water, sediments, yams, fish as well as soils. The atmospheric flux of mercury in the study area should be determined.

\section{Acknowledgement}

The technical advices of Joseph Ddumba Lwanyaga and Marion Engole of Busitema University and Robert Gazetti of Uganda Industrial Research Institute, Nakawa are appreciated.

\section{References}

1. Legg ED, Ouboter PE, Wright MAP. 2015. Small-scale gold mining related mercury contamination in the Guianas: A review. A report prepared for WWF Guianas. Available at http://assets.panda.org/downloads/hg_contamination_guianas_final_2july15.pdf. (accessed 29 July 2019).

2. United Nations Environment Programme. 2013. Global mercury assessment 2013: sources, emissions, releases and environmental transport; UNEP: Geneva, Switzerland. Available at https://www.zaragoza.es/contenidos/medioambiente/onu/942-eng.pdf (accessed 20 April 2019).

Peer) reviewing PDF | (2019:06:38591:2:0:ACCEPTED 16 Sep 2019) 
623 3. United Nations Environment Programme. 2012. Reducing Hg in ASGM: A practical guide.

624 UNEP: Nairobi, Kenya. Available at https://wedocs.unep.org/handle/20.500.11822/11524

625 (acessed 20 April 2019)

626 4. Africa Centre for Energy and Mineral Policy. 2017. Understanding artisanal and small-scale

627 mining operations in Uganda: A mapping study report. Available at

628 https://www.acemp.org/index.php/resources/reports (acessed 20 April 2019)

629 5. Combe AD. 1933. Buhweju mountains and part of the adjacent country. Department of 630 geological survey and mines, Uganda, annual report.

631 6. Armah FA. Artisanal gold mining and mercury contamination of surface water as a wicked

632 socio-environmental problem: a sustainability challenge?. 3rd world sustainability forum, 1st633 30th November 2013; 1-21.

634 7. The New Vision. 17th October 2018. Busia gets modern gold mining project. Available at 635 https://googleweblight.com/i?u=https://www.newvision.co.ug/new_vision/news/1487825/busia-

636 modern-gold-mining-project\&hl=en-UG (accessed 29 July 2019).

637 8. Veiga MM, Baker R. 2004. Protocols for environmental and health assessment of $\mathrm{Hg}$ released

638 by artisanal and small scale miners. Report to the global $\mathrm{Hg}$ project: removal of barriers to 639 introduction of cleaner ASGM and extraction technologies, GEF/UNDP/UNIDO.

640 9. Daily Monitor. Thursday, February 28 ${ }^{\text {th }}$ 2019. Miners warned on use of mercury. Available at

641 https://www.google.com/amp/s/www.monitor.co.ug/News/National/Miners-warned-on-use-

642 mercury/688334-5002504-view-asAMP-7gdbdgz/index.htm (accessed 26th May 2019).

643 10. Action Coalition Climate Change: Status and extent of mercury-use by artisanal and small644 scale gold miners in selected gold-mining sites of Mubende and Busia districts, Uganda. 645 Available at http://accc-u.org/wp-content/uploads/2018/08/ACCC-REPORT-ON-MERCURY646 2018-min.pdf (accessed 26th May 2019).

647 11. Streets DG, Hao J, Wu Y, Jiang J, Chan M, Tian HZ, Feng X. 2005. Anthropogenic Hg 648 emissions in China. Atmospheric Environment. 39 (40): 7789-7806

649 DOI: 10.1016/j.atmosenv.2005.08.029

650 12. Agency for Toxic Substances and Disease Registry. 2014. Medical management guideline 651 for mercury. Available at https://www.atsdr.cdc.gov/mmg/mmg.asp?id=106\&tid=24 (accessed 65226 May 2019).

653 13. Landrigan PJ \& Etzel RA. 2013. Textbook of Children's Environmental Health. Oxford: 654 Oxford University Press.

655 14. World Health Organization. Elemental mercury and inorganic mercury compounds: human 656 health aspects. Concise International Chemical Assessment Document 50. Geneva: World Health 657 Organization, 2003. Available at https:/www.who.int/ipcs/publications/cicad/en/cicad50.pdf 658 (accessed 26 May 2019).

659 15. Bose-O'Reilly S, McCarty KM, Steckling N, Lettmeier B. 2010. Mercury exposure and 660 children's health. Current Problems in Pediatric and Adolescent Health Care. 40 (8) : 186-215 661 DOI:10.1016/j.cppeds.2010.07.002

662 16. Spiegel SJ. 2009. Occupational health, mercury exposure, and environmental justice:

663 learning from experiences in Tanzania. American Journal of Public Health. 99 (3):550-558 DOI:

664 10.2105/AJPH.2008.148940 
665 17. World Health Organization. Environmental Health Criteria 101: methylmercury. Geneva:

666

667

668

669

670

671

672

673

674

675

676

677

678

679

680

681

682

683

684

685

686

687

688

689

690

691

692

693

694

695

696

697

698

699

700

701

702

703

704

705

International

Programme

on

Chemical

Safety,

1990.

http://www.inchem.org/documents/ehc/ehc/ehc101.htm\#SectionNumber:6.1 (accessed 5

February 2019).

18. Gibb H, O'Leary KG. 2014. Mercury exposure and health impacts among individuals in the artisanal and small-scale gold mining community: a comprehensive review. Environmental Health Perspectives. 122: 667-672. doi: 10.1289/ehp.1307864

19. National Environment Management Authority. 2012. National State of Environment Report for Uganda: Harnessing our Environment for Wealth Creation. Uganda.

20. Pfeiffer WC, Larceda LD. 1988. Mercury input into the Amazon region, Brazil. Environmental Technology Letters. 9: 325-330 DOI: 10.1080/09593338809384573

21. Meech JA, Veiga MM, Tromans D. 1998. Reactivity of Hg from gold mining activities in darkwater ecosystems. Ambio. 27(2): 92-98.

22. Santos-Frances F, Garcia-Sanchez A, Alonso-Rojo P, Contreras F, Adams M. 2011. Distribution and mobility of $\mathrm{Hg}$ in soils of a gold mining region, Cuyuni river basin, Venezuela. Journal of Environtal Management. 92:1268-76. DOI: 10.1016/j.jenvman

23. Ogola JS, Mitullah WV, Omulo MA. 2002. Impact of gold mining on the environment and human health: a case study in the Migori gold belt, Kenya. Environmental Geochemistry and Health. 24:141-158 DOI: 10.1023/A:1014207832471

24. Garcia-Sanchez A, Contreras F, Adams M, Santos F. 2016. Atmospheric mercury emissions from polluted gold mining areas (Venezuela). Environmental Geochemistry and Health. 28:529540 DOI: $10.1007 / \mathrm{s} 10653-006-9049-\mathrm{x}$

25. Mroz JP, Urien P, Baguma Z, Viallefond L. 1991. Gold exploration in Busia area, Uganda (Phase 1). BRGM Report R 32761.

26. Rwabwoogo MO. 1998. Uganda districts information handbook. 5th Edition. Fountain Publishers Limited, Kampala.

27. Mbonimpa A. 2005. The genesis and characteristics of the gold mineralisation in the area between River Malaba and River Solo in Busia district, South eastern Uganda. MSc dissertation, Makerere University.

28. COWI. 2016. Country reports on mercury trade and use for ASGM. Appendix to the report "Mercury trade and use for ASGM in Sub-Saharan Africa". Available at http://cegemi.com/wpcontent/uploads/2016/02/Mercury-Sub-Saharan-Africa-Trade-Report-12-December.pdf (accessed 28 June 2019)

29. UNEP. 1992. Determination of petroleum hydrocarbons in sediments. Geneva, Switzaland: UNESCO.

30. Salomons W and Forstner U. 1984. Metals in the hydrocycle, Springer-Verlag, Berlin, Heidelberg, New York, Tokyo. DOI: 10.1002/aheh.19850130225

31. Omara T, Ogwang R, Ndyamuhaki S, Kagoya S, Kigenyi E, Musau B, Adupa E. 2018. Spectroscopic analysis of selected priority trace metals in the extant East African gilled lungfish (Protopterus amphibius) in Lira municipal lagoon and its edibility health risk. Science Journal of Analytical Chemistry. 6(5):38-45. DOI: 10.11648/j.sjac.20180605.11

Peer] reviewing PDF | (2019:06:38591:2:0:ACCEPTED 16 Sep 2019) 
706 32. Khansari FE, Ghazi-Khansari M, Abdollahi. 2005. Heavy metal content of canned Tuna fish.

707 Food Chemistry. 93(2): 293-296. DOI:10.1016/j.foodchem.2004.09.025

708 33. USEPA. 2001. Appendix to method 1631. Total mercury in: tissue, sludge, sediment and soil 709 by acid digestion and $\mathrm{BrCl}$ oxidation.

710 34. Heimbürger L-E, Sonke JE, Cossa D, Point D, Lagane C, Laffont L, Galfond BT, Nicolaus 711 M, Rabe B, Van Der Loeff MR. 2015. Shallow methylmercury production in the marginal sea 712 ice zone of the central Arctic Ocean. Scientific Reports. 5, 10318. DOI: 10.1038/srep10318.

713 35. Appendix to Method 1631. Total mercury in tissues, sediment, and soil by acid digestion and $714 \mathrm{BrCl}$ oxidation. EPA-821-R-01-013, January 2001.

715 36. Brooksrand Instruments. Manual mercury systems. Available at

716 http://www.brooksrandinc.com/products/manual-mercury-systems/total-mercury-manual-system/ 717 (accessed 20 July 2019).

718 37. Nowell LH, Moran PW, Gilliom RJ, Calhoun DL, Ingersoll CG, Kemble NE, Kuivila KM, 719 Phillips PJ. 2013. Contaminants in stream sediments from seven United States metropolitan 720 areas: Part I: distribution in relation to urbanization. Archives of Environmental Contamination 721 and Toxicology. 64:32-51. DOI: 10.1007/s00244-012-9813-0

722 38.Superfund Public Health Evaluation Manual. 1986. US EPA, Washington DC, USA. p. 1-86.

723 39. Ordonez A, Alvarez R, Charlesworth S, De Miguel E, Loredo J. Risk assessment of soils 724 contaminated by mercury mining, Northern Spain. 2011. Journal of Environmental Monitoring. 725 13:128. DOI: 10.1039/c0em00132e

726 40. Bamuwamye M, Ogwok P, Tumuhairwe V, Eragu R, Nakisozi H, Ogwang PE. 2017. Dietary 727 content and potential health risks of metals in commercial black tea in Kampala (Uganda). 728 Journal of Food Research. 6(6):1-12 DOI: 10.5539/jfr.v6n6p1

729 41. Wang X, Sato T, Xing B, Tao S. 2005. Health risks of heavy metals to the general public in 730 Tianjin, China via consumption of vegetables and fish. Science of the Total Environment. 731 350:28-37. DOI: 10.1016/j.scitotenv.2004.09.044

732 42. Ge KY. 1992. The status of nutrient and meal of Chinese in the 1990s. Journal of 733 Environment Pollution and Human Health. 1(1): 1-5.

734 43. Adedokun AH, Njoku KL, Akinola MO, Adesuyi AA, Jolaoso AO. Potential human health 735 risk assessment of heavy metals intake via consumption of some leafy vegetables obtained from 736 four market in Lagos Metropolis, Nigeria. 2016. Journal of Applied Science and Environmental 737 Management. 20:530-539. DOI: 10.4314/jasem.v20i3.6

738 44. Ali M, Hau VTB. 2001. Vegetables in Bangladesh: Economic and nutritional impact of new 739 varieties and technologies. Technical bulleting No. 25 Tainan, Taiwan. The World Vegetable 740 Center (AVRDC). Available at http://203.64.245.61/fulltext_pdf/EB/2001-2010/TB25.pdf. 741 accessed 30 May 2019)

742 45. Saha N, Zaman MR. 2012. Evaluation of possible health risks of heavy metals by 743 consumption of foodstuffs available in the central market of Rajshahi City, Bangladesh. 744 Environmental Monitoring and Assessment. 185:3867-78. DOI: 10.1007/s10661-012-2835-2

745 46. Wojciechowska E, Nawrot N, JolantaWalkusz-Miotk, Matej-Łukowicz K, Pazdro K. 2019. 
746 Heavy metals in sediments of urban streams: contamination and health risk assessment of

747 influencing factors. Sustainability.11: 563. DOI:10.3390/su11030563

748 47. US EPA. 2009. Risk-based concentration table. United States Environmental Protection

749 Agency: Washington DC.

750 48. Qing X, Yutong Z, Shenggao L. 2015. Assessment of heavy metal pollution and human

751 health risk in urban soils of steel industrial city (Anshan), Liaoning, Northeast China. Ecotoxicol

752 Environ Saf. 120:377-85. DOI: 10.1016/j.ecoenv.2015.06.019

753 49. USEPA. 1989. Risk assessment guidance for superfund, human health evaluation manual

754 Part A. Interim Final vol. I, United States Environmental Protection Agency, Washington DC.

755 50. Cooper CB, Doyle ME, Kipp K. 1991. Risk of consumption of contaminated seafood, the

756 Quincy Bay case study. Environmental Health Perspectives. 90:133-140. DOI: 10.1289/ehp.90-

$757 \quad 1519503$

758 51. US EPA. Bioaccumulation testing and interpretation for the purpose of sediment quality

759 assessment. U.S. Environmental Protection Agency (2000) EPA-823-R-00-001.

760 52. Nsikak UB, Anake WU, Essien JP, Enyong P, Olajire AA. 2017. Distribution and risk

761

762

763

764

765

766

767

768

769

770

771

772

773

774

775

776

777

778

779

780

781

782

783

784

785

786

787

788

assessment of trace metals in Leptodius exarata, surface water and sediments from Douglas creek in the Qua Iboe Estuary. Journal of Taibah University for Science. 11(3): 434-449.DOI: 10.1016/j.jtusci.2016.08.004

53. Hakanson L. 1980. An ecological risk index for aquatic pollution control. A sedimentological approach. Water Research. 14 (8) : 975-1001. DOI:10.1016/0043-1354(80)90143-8

54. Tomlinson DL, Wilson JG, Harris CR, Jeffrey DW. 1980. Problems in the assessment of heavy-metal levels in estuaries and the formation of a pollution index. Helgoländer Meeresuntersuchungen. 33:566-575. DOI: 10.1007/BF02414780

55. Zheng X, Zhao W, Yan X, Shu T, Xiong Q, Chen F. 2015. Pollution characteristics and health risk assessment of airborne heavy metals collected from Beijing bus stations. International Journal of Environmental Research and Public Health. 12: 9658-71. DOI: 10.3390/ijerph120809658

56. Taylor SR. 1964. The abundance of chemical elements in the continental crust- A new table. Geochimica Cosmochimica Acta. 28:1273-1285. DOI: 10.1016/0016-7037(64)90129-2

57. Müller G. 1981. Die Schwermetallbelastung der Sedimenten des Neckars und Seiner Nebenflüsse. Chemiker-Zeitung. 6:157-164.

58. Chen CW, Kao CM, Chen CF, Dong CD. 2007. Distribution and accumulation of heavy metals in the sediments of Kaohsiung harbor, Taiwan. Chemosphere. 66(8):1431-40. DOI:

10.1016/j.chemosphere.2006.09.030

59. Zhang W, Feng H, Chang J, Qu J, Xie H, Yu L. 2009. Heavy metal contamination in surface sediments of Yangtze river intertidal zone: an assessment from different indexes. Environmental Pollution. 157:1533-43. DOI: 10.1016/j.envpol.2009.01.007

60. International Programme on Chemical Safety. 1989. Hg-environmental aspects. Geneva, W.H.O., International Programme on Chemical Safety (Environmental Health Criteria 86).

61. Ramesh MSR, Chandran KS, Sreedharan, Mohan M. 2012. Hg contamination in the artisanal gold mining regions of Nilambur, Kerala, South India. Journal of Environment. 01(01):7-13.

62. Wood JM, Wang HK. 1983. Microbial resistance to heavy metals. Environmental Science Technology. 17(12) : 82A-90A. DOI: 10.1021/es00118a002

PeerJ reviewing PDF | (2019:06:38591:2:0:ACCEPTED 16 Sep 2019) 
789

790

791

792

793

794

795

796

797

798

799

800

801

802

803

804

805

806

807

808

809

810

811

812

813

814

815

816

817

818

819

820

821

822

823

824

825

826

827

828

829

830

63. Gilmour CC, Henry EA, Mitchell R. 1992. Sulphate stimulation of Hg methylation in fresh water sediments. Environmental Science Technology. 26(11):2281-87. DOI: 10.1021/es00035a029.

64. Alvarez MB, Domini CE, Garrido M, Lista AG, Fernandez-Band BS. 2007. Single-step chemical extraction procedures and chemometrics for assessment of heavy metal behaviour in sediment samples from the Bahia Blanca estuary, Argentina. Journal of Soils and Sediments. 11(4): 657-66.

65. Caille N, Tiffreau C, Leyval C and Morel JL. 2003. Solubility of metals in an anoxic sediment during prolonged aeration. Science of the Total Environment. 301(1-3): 239-250.

DOI: $10.1016 / \mathrm{s} 0048-9697(02) 00289-9$

66. Hill NA, Simpson SL, Johnston EL. 2013. Beyond the bed: effects of metal contamination on recruitment to bedded sediments \& overlying substrata. Environmental Pollution. 173:182-91.

DOI: 10.1016/j.envpol.2012.09.029

67. Gabriel M, Williamson, D. 2004. Principal biogeochemical factors affecting the speciation and transport of $\mathrm{Hg}$ through the terrestrial environment. Environmental Geochemistry and Health. 26(3-4) : 421- 434. DOI: 10.1007/s10653-004-1308-0

68. Kim C, Rytuba JJ, Brown JGE. 2004. EXAFS study of Hg (II) sorption to Fe- and Al(hydroxides) I. Effect of $\mathrm{pH}$. Journal of Colloid Interface Science. 271: 1-15. DOI: 10.1016/S0021-9797(03)00330-8

69. Lino AS, Kasper D, Guida YS, Thomaz JR, Malm O. 2019. Total and methyl mercury distribution in water, sediment, plankton and fish along the Tapajós River basin in the Brazilian Amazon. Chemosphere. 235: 690-700. DOI: 10.1016/j.chemosphere.2019.06.212

70. Oladipo SI, Kehinde MA, Osaguona P, Ajayi J. 2013. Hg contamination in ASGM area of Manyera river, Niger state Nigeria. E3 Journal of Environmental Research Management. 4(9):0326-0333.

71. Mahre MY, Akan JC, Moses EA, Ogugbuaja VO. 2007. Pollution Indicators in River Kaduna, Kaduna State, Nigeria. Trends in Applied Science Research. 2(4): 304-311. 10.3923/tasr.2007.304.311

72. Nabaasa H. 2016. Artisanal and small-scale gold mining and food security. An ecological perspective. African Journal of Public Affairs. 9(4): 145-155.

73. Mubende District Local Government. 2013. Environmental Challenges of artisanal gold mining: District development plan: Mubende district local government annual report. Kampala.

74. Duyusen GE, Gorkem A. 2008. Heavy metals partitioning in the sediments of Izmir Inner Bay. Journal of Environmental Science. 35(4): 413-418.

75. Yu R, Yuan X, Zhao Y, Hu G, Tu X. 2008. Heavy metal pollution in intertidal sediments from Quanzhou Bay, China. Journal of Environmental Sciences. 20(6): 664-69. DOI: 10.1016/s1001-0742(08)62110-5

76. Orson RA, Simpson RL, Good RE. 1992. A mechanism for the accumulation and retention of heavy metals in tidal freshwater marshes of the upper Delaware river estuary. Estuarine, Coastal and Shelf Science. 34(2):171-186. DOI: 10.1016/S0272-7714(05)80103-9

77. Singh RP, Huerta-Espino J, William HM. 2005. Genetics and breeding for durable resistance to leaf and stripe rusts in wheat. Turkish Journal of Agriculture and Forestry. 29:121-27.

PeerJ reviewing PDF | (2019:06:38591:2:0:ACCEPTED 16 Sep 2019) 
831 78. Marchand C, Lalliet VE, Baltzer F, Alberic P, Cossa D, Baillif P. 2006. Heavy metals 832 distribution in mangrove sediments along the mobile coastline of French Guiana. Marine 833 Chemistry.98 (1) :1-17. DOI: 10.1016/j.marchem.2005.06.001

834 79. Ahmad MK, Islam S, Rahman S, Haque MR, Islam MM. 2010. Heavy metals in water, 835 sediment and some fishes of Buriganga river, Bangladesh. International Journal of 836 Environmental Research. 4(2):321-332. DOI: 10.22059/IJER.2010.24

837 80. Bastami KD, Bagheri H, Haghparast S, Soltani F; Hamzehpoor A, Bastami MD. 2012. 838 Geochemical and geo-statistical assessment of selected heavy metals in the surface sediments of 839 the Gorgan Bay, Iran. Marine Pollution Bullettin. 64 (12) : 2877-84.

840 DOI: 10.1016/j.marpolbul.2012.08.015.

841 81. Tavakoly Sany SB, Hashim R, Rezayi M, Salleh A, Safari O. 2013. A review of strategies to 842 monitor water and sediment quality for a sustainability assessment of marine environment. 843 Environmental Science and Pollution Research. 21(2) :813-833. DOI: 10.1007/s11356-013$844 \quad 2217-5$

845 82. Alves RIS, Sampaio CF, Nadal M, Schuhmacher M, Domingo JL, Seguramuñoz SI. 2014. 846 Metal concentration in surface water and sediments from Pardo River, Brazil: human health 847 risks. Environmental Research. 133:149-155. DOI: 10.1016/j.envres.2014.05.012

848 83. Sayadi MH, Rezaei MR, RashkiGhaleno O, Afsari K, Poor Mollaei N. 2015. Natural and 849 concentration factor distribution of heavy metals in sediments of Chah Nimeh reservoirs of 850 Sistan. Ecopersia. 3 (2): 1003-12.

851 84. Shirneshan G, Riahibakhtiari A, Sayfabadi SJ, Mortazavi S. 2013. Environmental 852 geochemistry of $\mathrm{Cu}, \mathrm{Zn}$ and $\mathrm{Pb}$ in sediment from Qeshm island, Persian gulf, Iran: A comparison 853 between the northern and southern coast and ecological risk. Geochemistry International. 5(8): 854 670-76.

855 85. Yap CK, Ismail A, Tan SG, Omar H. 2002. Correlations between speciation of Cd, Cu, $\mathrm{Pb}$ 856 and $\mathrm{Zn}$ in sediment and their concentrations in total soft tissue of green-lipped mussel 857 Pernaviridis from the west coast of Peninsular Malaysia. Environment International. 28 (1-2):

858 117-126. DOI:10.1016/S0160-4120(02)00015-6

859 86. Long ER, Robertson A, Wolfe DA, Hameedi J, Sloane GM. 1996. Estimates of the spatial 860 extent of sediment toxicity in major US estuaries. Environ Science Technology. 30 (12): 3585861 92. DOI: 10.1021/es9602758

862 87. Fichet D, Bowher G, Radenac G, Miramand P. 1999. Concentration and mobilisation of Cd, $863 \mathrm{Cu}, \mathrm{Pb}$ and $\mathrm{Zn}$ by meio fauna populations living in harbour sediment: their role in the heavy 864 metal flux from sediment to food web. Science of the Total Environment. 243(15):263-72.

865 DOI: 10.1016/s0048-9697(99)00401-5

866 88. Gognou C and Fisher NS. 1997. The bioavailability of sediment bound Cd, Co and Ag to the 867 mussel Mytilusedulis. Canadian Journal of Fisheries and Aquatic Sciences. 54 (1) : 147-156. 868 DOI: 10.1139/f96-256

869 89. Birch GF. 2003. A scheme for assessing human impacts on coastal aquatic environments 870 using sediments. In: Woodcoffe CD, Furness RA (eds) Coastal GIS: an integrated approach to 871 Australian coastal issues.Wollongong University Papers in Center for Maritime Policy, 14, 872 Australia. 
873 90. Morillo J, Usero J, Gracia I. 2004. Heavy metal distribution in marine sediments from the 874 southwest coast of Spain. Chemosphere. 55:431-42. DOI: 10.1016/j.chemosphere.2003.10.047

875 91. Aderinola OJ, Clarke EO, Olarinmoye OM, Kusemiju V, Anatekhai MA. 2009. Heavy 876 metals in surface water, sediments, fish and Perwinkles of Lagos Lagoon. American-Eurasian 877 Journal of Agricultural and Environmental Science . 5(5):609-17.

878 92. Abdollahi S, Raouf Z, Faghiri I, Savari A, Nikpour Y, Mansouri A. 2013. Contamination 879 levels and spatial distributions of heavy metals and PAHs in surface sediment of Imam Khomeini 880 port, Persian gulf, Iran. Marine Pollution Bulletin. 71:336-345. 881 DOI:10.1016/j.marpolbul.2013.01.025

882 93. Islam MS, Ahmed MK, Habibullah-Al-Mamun M, Hoque MF. 2015. Preliminary assessment 883

884 of heavy metal contamination in surface sediments from a river in Bangladesh. Environ Earth Sci. 73:1837-48.

886 94. Mir MA, Mohammad LA, Md SI, Md ZR. 2016. Preliminary assessment of heavy metals in water and sediment of Karnaphuli River, Bangladesh. Environmental Nanotechology, Monitoring and Management. 5:27-35. DOI:10.1016/j.enmm.2016.01.002

889 95. Donkor AK, Bonzongo JC, Nartey VK, Adotey DK. 2006. Hg in different environmental compartments of the Pra river basin, Ghana. Science of the Total Environment. 368(1):164-176.

891

892

893

894

895

896

897

898

899

900

901

902

903

904

905

906

907

908

909

910

911

912

913 DOI: 10.1016/j.scitotenv.2005.09.046

96. Ramirez-Requelme ME, Ramos JFF, Angelica RS, Brabo ES. 2003. Assessment of Hgcontamination in soils and streams sediments in the mineral district of Nambija, Ecuadorian Amazon (example of an impacted area affected by ASGM). Applied Geochemistry. 18:371-381. DOI: 10.1016/S0883-2927(02)00088-4

97. Feng X, Dai Q, Qiu G, Li G, He L, Wang D. 2006. Gold mining related mercury contamination in Tongguan, Shaanxi Province, PR China. Journal of Applied Geochemistry. 21:1955-68. DOI:10.1016/j.apgeochem.2006.08.014

98. Lasut MT, Yasuda Y, Edinger EN, Pangemanan JM. Distribution and accumulation of Hg derived from gold mining in marine environment and its impact on residents of Buyat Bay, North Sulawesi, Indonesia. 2010. Journal of Water, Air and Soil Pollution. 208: 153-164. DOI: 10.1007/s 11270-009-0155-0

99. Pataranawata RP, Parkpianb P, Polprasertb C, Delaunec RD, Jugsujindaa A. 2007. Hg emission and distribution: Potential environmental risks at a small-scale gold mining operation, Phichit Province, Thailand. Journal of Environmental Science and Health, Part A. 42(8):108193. DOI:10.1080/10934520701418573

100. Taylor H, Appleton JD, Lister R, Smith B, Chitamweba D, Mkumbo O, Machiwa JF, Tesha AL, Beinhoff C. 2005. Environmental assessment of mercury contamination from the Rwamagasa ASGM centre, Geita district, Tanzania. Science of the Total Environment. 343:11133. DOI:10.1016/j.scitotenv.2004.09.042

101. Smith SL, MacDonald DD, Keenleyside KA, Gaudet CL. The development and implementation of Canadian sediment quality guidelines. In: Munawar, M., and Dave, G. eds. Development and progress in sediment quality assessment: rationale, challenges, techniques and strategies. Amsterdam, SPB Academic Publishing. 233-249. 
914 102. MacDonald DD. 1994. Approach to the assessment of sediment quality in Florida coastal 915 waters. Vol. 1-Development and evaluation of sediment quality assessment guidelines. Florida 916 Department of Environmental Protection Office of Water Policy.

917 103. Forstner U, Wittman GTW. Metal Pollution in the Aquatic environment. Berlin, Springer 918 Verlag. 1981; pp. 486. DOI : 10.1007/978-3-642-69385-4

919 104. Haines ML, Brydges K, MacDonald MJ, Smith SL, MacDonald DD. 1994. A review of 920 environmental quality criteria and guidelines for priority substances in the Fraser river basin. 921 Supporting documentation. DOE FRAP 1994-31. Vancouver environment Canada.

922 105. Castilhos ZC, Rodrigues-Filho S, Rodrigues APC, Villas-Bôas RC, Siegel S, Veiga MM, 923 Beinhoff C. 2006. Hg contamination in fish from gold mining areas in Indonesia and human 924 health risk assessment. Science of the Total Environment. 368(1): 320-325. DOI: 925 10.1016/j.scitotenv.2006.01.039

926 106. Burger J, Gaines KF, Boring CS, Stephens WL, Snodgrass J, Dixon C. 2002. Metal levels in 927 fish from the Savannah river: potential hazards to fish and other receptors. Environmental 928 Research, Section A. 89(1): 85-97. DOI: 10.1006/enrs.2002.4330

929 107. Ahmed AK, Shuhaimi-Othman M. 2010. Heavy metal concentrations in sediments and 930 fishes from Lake Chini, Pahang, Malaysia. Journal of Biological Sciences.10(2):93-100. 931 DOI:10.3923/jbs.2010.93.100

932 108. Koca YBM, Koca S, Yildiz S, Gurcu B, Osanc E, Tuncbas O. 2005. Investigation of 933 histopathological \& cytogenetic effects on Lepomis gibbosus (Pisces: Perciformes) in the Cine 934 stream (Aydin/Turkey) with determination of water pollution. Environmental Toxicology. 935 20:560-71. DOI: 10.1002/tox.20145

936 109. Mol JH, Ramlal JS, Lietar C, Verloo M. 2011. Mercury contamination in freshwater, 937 estuarine, and marine fishes in relation to small-scale gold mining in Suriname, South America.

938 Environmental Research. 86(2):183-197. DOI: 10.1006/enrs.2001.4256

939 110. Marrugo-Negrete J, Norberto LB, Olivero-Verbel J. 2008. Distribution of mercury in 940 several environmental compartments in an aquatic ecosystem impacted by gold mining in 941 Northern Colombia. Archives of Environmental Contamination and Toxicology. 55:305-316. 942 DOI: 10.1007/s00244-007-9129-7

943 111. Weber P, Behr ER, Knorr CDL, Vendruscolo DS, Flores EMM, Dressler VL, Baldisserotto 944 B. 2013. Metals in the water, sediment and tissues of two fish species from different trophic 945 levels in a subtropical Brazilian river. Microchemical Journal. 106:61-66. DOI: 946 10.1016/j.microc.2012.05.004

947 112. Rae D, Graham L. 2012. Benefits of reducing mercury in saltwater ecosystems: a case 948 study; Biblio Bazaar: Charleston, SC, USA.

949 113. AMAP. 2003. AMAP Assessment 2002: Human Health in the Arctic; AMAP: Oslo, 950 Norway. Available at https://www.amap.no/documents/doc/amap-assessment-2002-human951 health-in-the-arctic/95 (accessed 20 June 2019)

952 114. Gray JE, Labson VF, Weaver JN, Krabbenhoft DP. 2002. Mercury and methylmercury 953 contamination related to artisanal gold mining, Suriname. Geophysical Research Letters. 29(23): 954 2105. DOI :10.1029/2002GL015575

955 115. Nartey VK, Klake RK, Hayford EK, Doamekpor LK, Appoh RK. 2011. Assessment of mer956 cury pollution in rivers and streams around artisanal gold mining areas of the Birim North 
957 District of Ghana. Journal of Environmental Protection. 2(9): 1227-39. 958 DOI: $10.4236 /$ jep.2011.29141

959 116. Diringer SE, Feingold BJ, Ortiz EJ, Gallis JA, Araújo-Flores JM, Pan WKY, Hsu-kim H. 960 2015. River transport of mercury from artisanal and small-scale gold mining and risks for dietary 961 mercury exposure in Madre de Dios, Peru. Environmental Science Process Impacts. 478-487. 962 DOI: $10.1039 / \mathrm{c} 4 \mathrm{em} 00567 \mathrm{~h}$.

963 117. Bortey-Sam N, Nakayama SMM, Ikenaka Y, Akoto O, Baidoo E, Yohannes YB, Mizukawa 964 H, Ishizuka M. 2005. Human health risks from metals and metalloid via consumption of food 965 animals near gold mines in Tarkwa, Ghana: Estimation of the daily intakes and THQs. 966 Ecotoxicology and Environmental Safety. 111:160-67. DOI: 10.1016/j.ecoenv.2014.09.008

967 118. Huang SS, Liao QL, Hua M, Wu XM, Bi KS, Yan CY, Chen B, Zhang XY. 2007. Survey 968 of heavy metal pollution and assessment of agricultural soil in Yangzhong district, Jiangsu 969 Province, China. Chemosphere. 67:2148-55. DOI: 10.1016/j.chemosphere.2006.12.043

970 119. Liu H, Probst A, Liao B. 2005. Metal contamination of soils and crops affected by the 971 Chenzhou lead/zinc mine spill (Hunan, China). Science of the Total Environment. 339:153-166.

972 DOI:10.1016/j.scitotenv.2004.07.030.

973 120. Japan Environmental Agency. Quality of the Environment in Japan-1989; Tokyo. available 974 at https://www.env.go.jp/en/wpaper/1989/eae180000000030.html (accessed 20 June 2019)

975 121. Oyewo EO, Don-Pedro KN. 2003. Acute toxicity and bioaccumulation of mercury and 976 copper in Clibanarius africanis (Aurivillus) and Tympanotonos fuscatus (Linne). Journal of 977 Aquatic Science. 18.2: 75-84. DOI:10.4314/jas.v18i2.19947

978 122. Avelar WEP, Mantelatto FLM, Tomazelli AC, Silva DML, Shuhama T, Lopes JLC. 2000. 979 The marine mussel Perna perna (Mollusca, Bivalvia, Mytilidae) as an indicator of contamination 980 by heavy metals in the Ubatuba Bay, Sao Paulo, Brazil. Water, Air and, Soil Pollution. 118:65981 72. DOI: 10.1023/A:1005109801683

982 123. Kwok CK, Liang Y, Wang H, Dong YH, Leung SY, Wong MH. 2005. Bioaccumulation of 983 heavy metals in fish and Ardeid at Pearl River Estuary, China. Ecotoxicology and Environmental 984 Safety. 106:62-67. DOI: 10.1016/j.ecoenv.2014.04.016

985 124. Zhao S, Feng C, Quan W, Chen X, Niu J, Shen Z. 2012. Role of living environments in the 986 accumulation characteristics of heavy metals in fishes and crabs in the Yangtze River Estuary, 987 China. Marine Pollution Bulletin. 64 (6):1163-71. DOI: 10.1016/j.marpolbul.2012.03.023. 
Figure 1

Map of Busia gold district showing the location of Namukombe stream. Inset is the location of Busia gold district on the map of Uganda (Adapted from Mbonimpa, 2005)

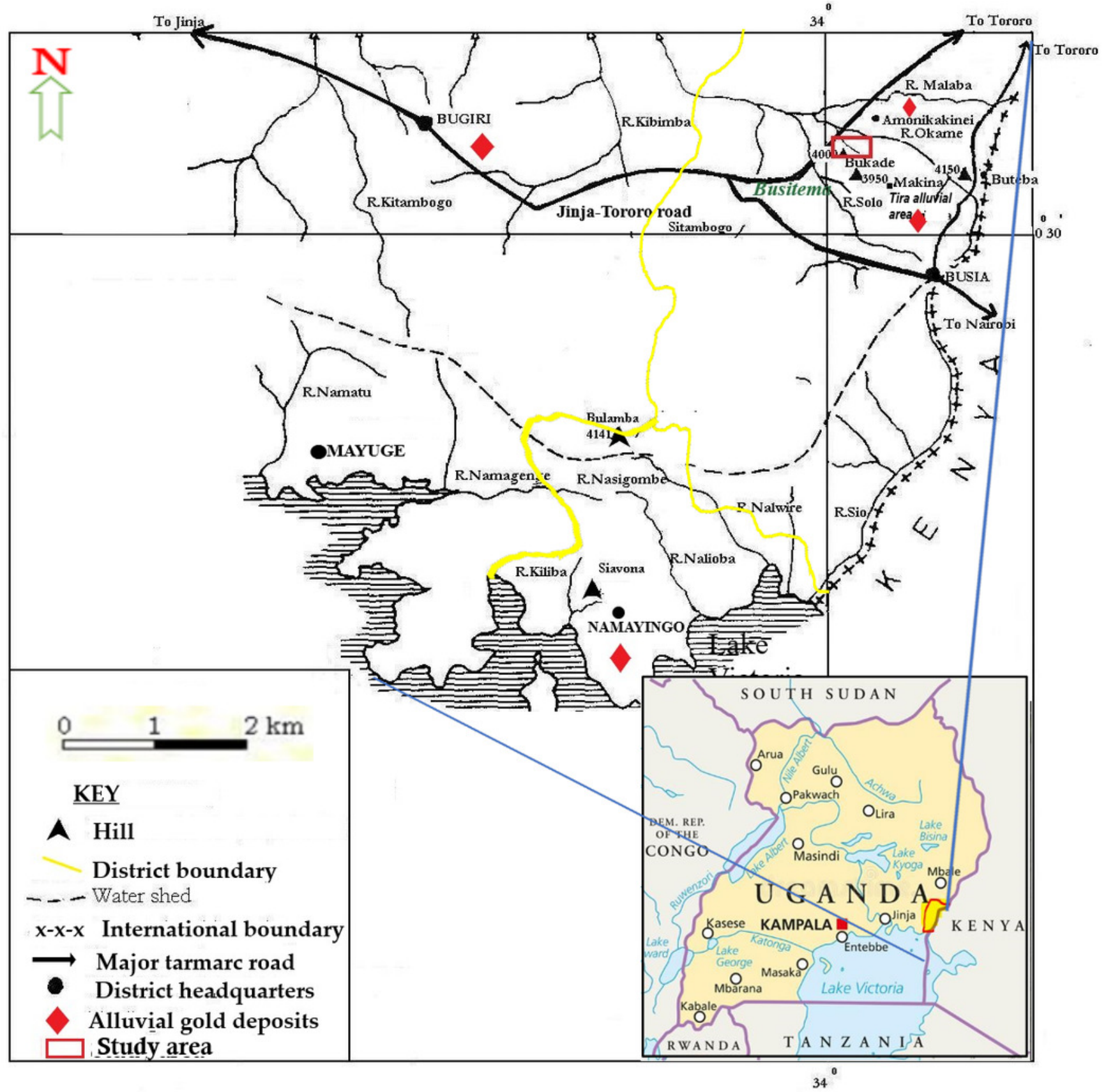


Figure 2

Panning of alluvium in Namukombe stream

(a) at the first gold recovery site (up sluice) by school dropouts (children); (b) at the third gold recovery site (down sluice) by a man(Photo credit: Shakilah Karungi)

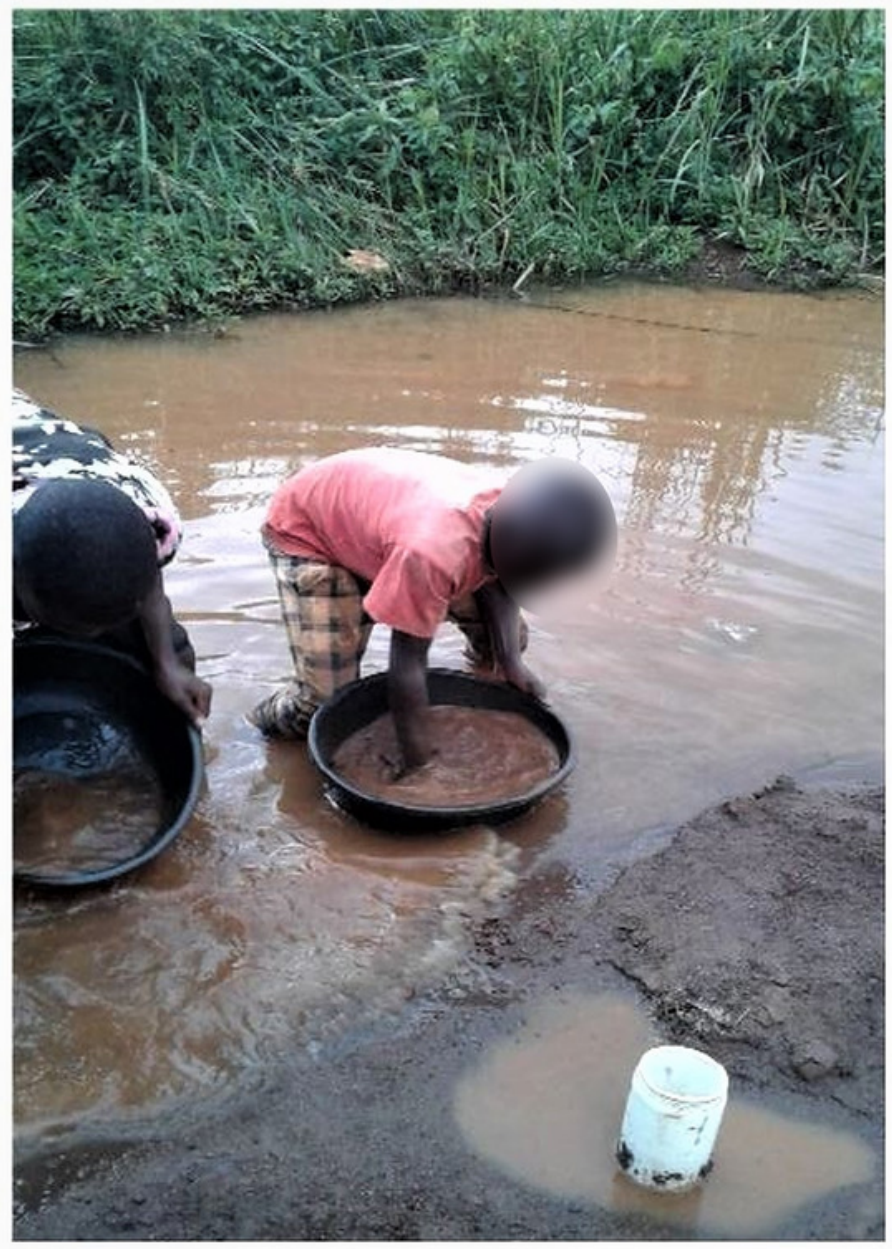

(a)

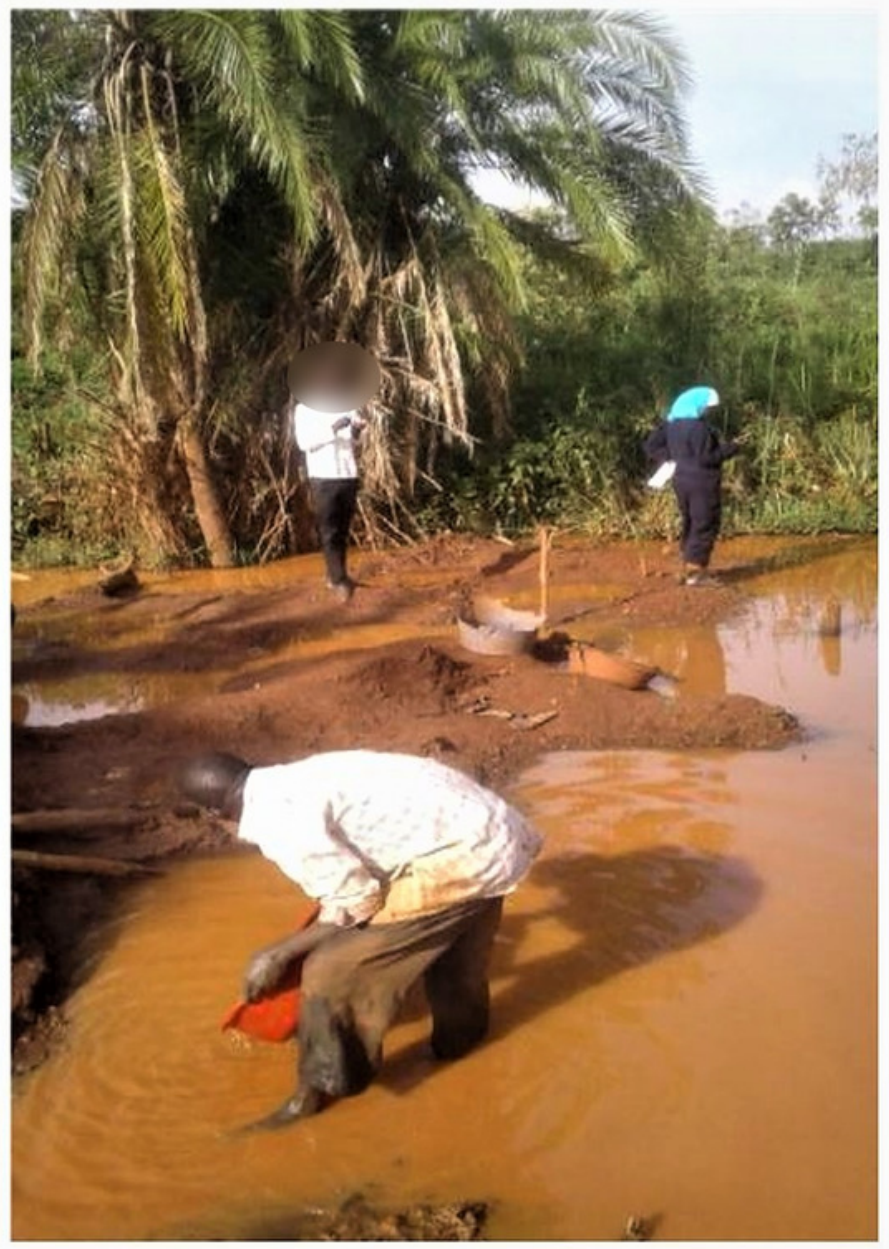

(b) 


\section{Figure 3}

Map of Namukombe stream showing the location of the sampled sluices

1,2 and 3 are the gold recovering sites located along the banks of the stream approximately $800 \mathrm{~m}$ from each other. Map data $\odot 2019$ OpenStreetMap contributors

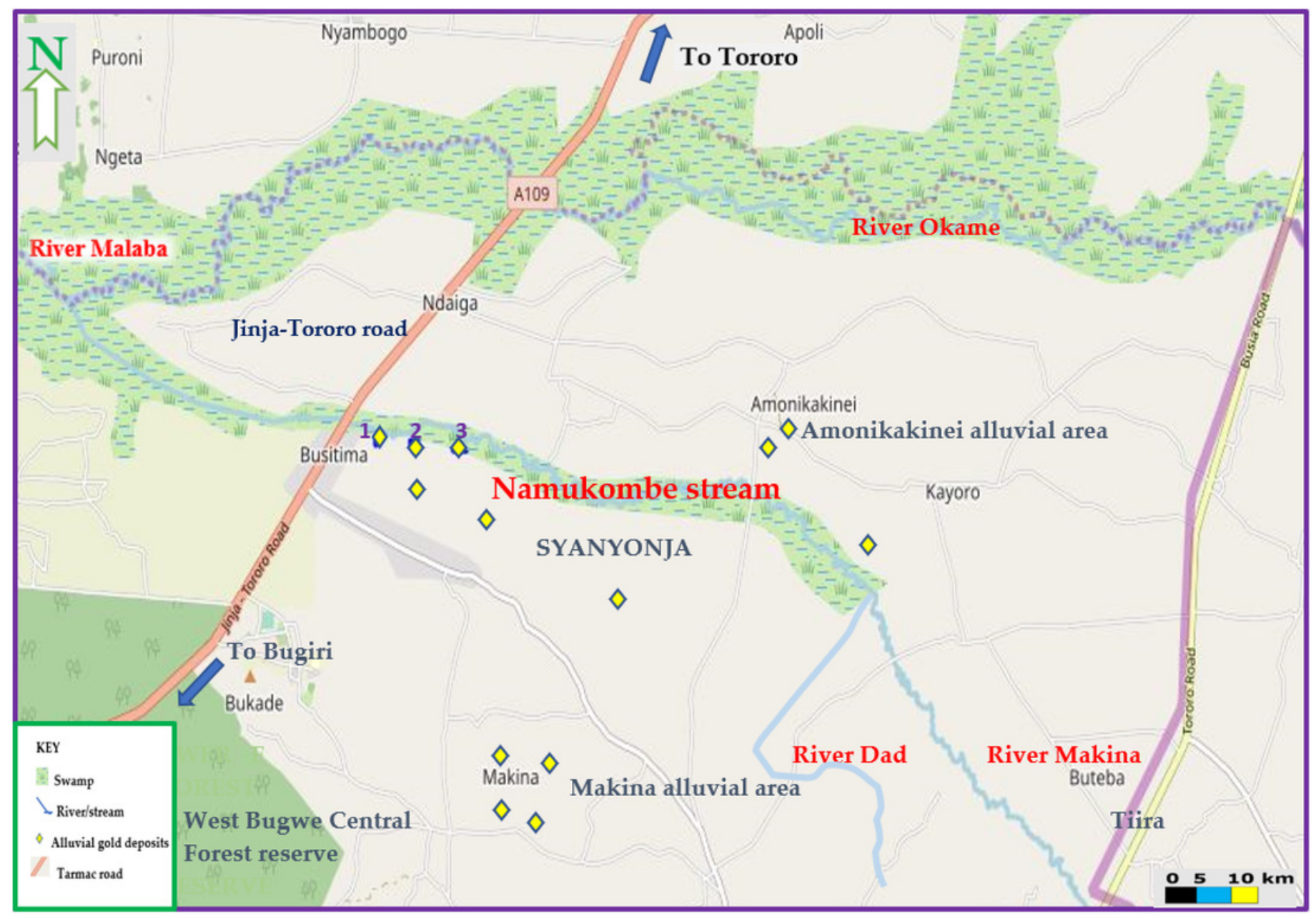


Figure 4

Sampling plan for water, sediments, fish and yams from Namukombe stream

Yam and fish samples were taken from within a maximum of $5 \mathrm{~m}$ radius from the sampling points indicated in the plan.

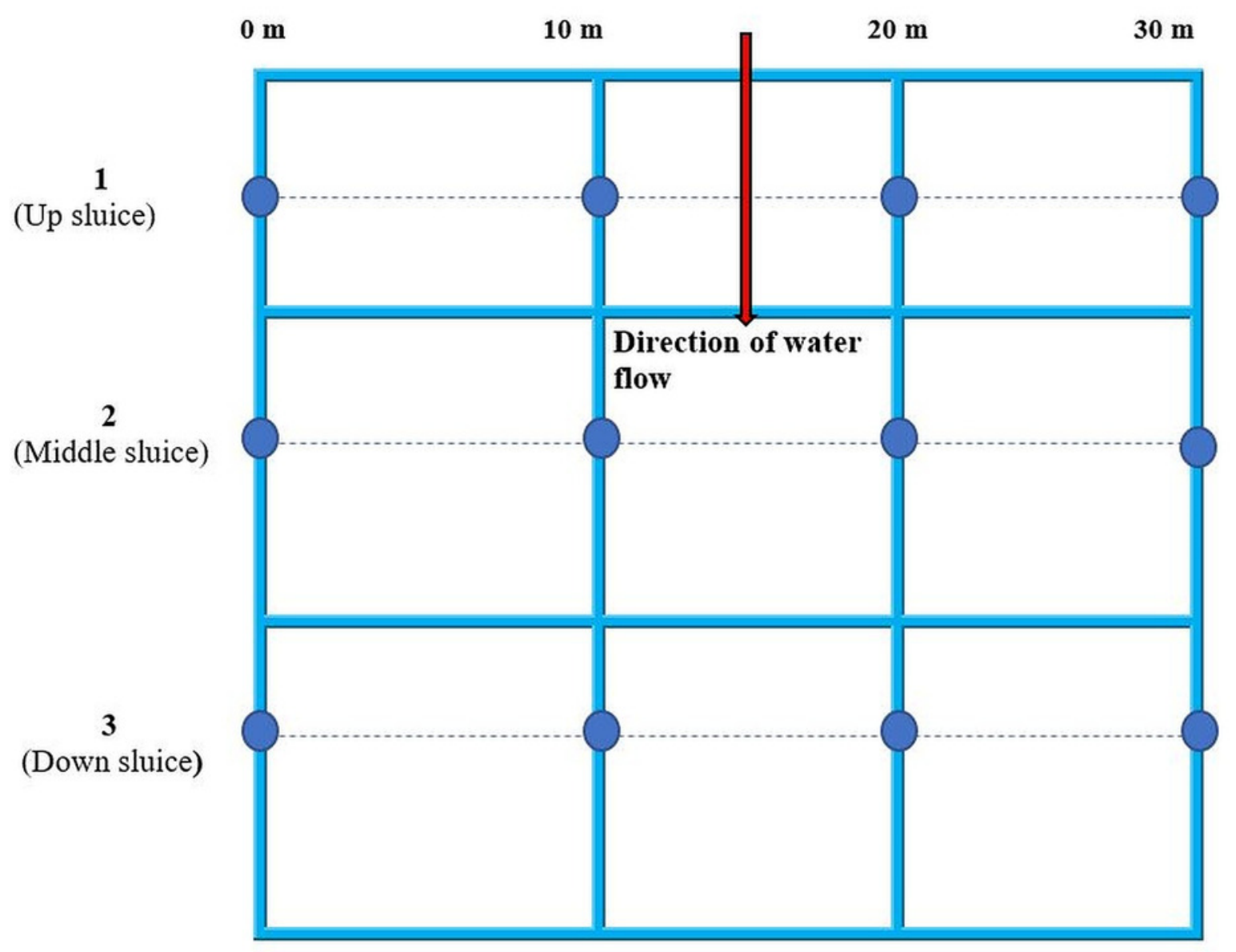




\section{Table $\mathbf{1}$ (on next page)}

Mercury content of water, sediments, fish and yams from Namukombe stream 
Table 1. Mercury content of water, sediments, fish and yams from Namukombe stream

\begin{tabular}{|c|c|c|c|c|c|c|c|}
\hline \multirow[t]{3}{*}{ Sample } & \multirow{3}{*}{$\begin{array}{l}\text { Distance } \\
\text { (m) }\end{array}$} & \multicolumn{6}{|c|}{ Total mercury concentration $\left(\mathrm{mg} / \mathrm{L}\right.$ or $\left.\mu \mathrm{gg}^{-1}\right)$} \\
\hline & & \multicolumn{2}{|c|}{ Up sluice } & \multicolumn{2}{|c|}{ Middle sluice } & \multicolumn{2}{|l|}{ Down sluice } \\
\hline & & Mean \pm S.D & Range & Mean \pm S.D & Range & Mean \pm S.D & Range \\
\hline \multirow[t]{4}{*}{ Surface water } & 0 & $1.21 \pm 0.040$ & $1.17-1.25$ & $0.18 \pm 0.070$ & $0.11-0.25$ & $0.10 \pm 0.030$ & $0.07-0.13$ \\
\hline & 10 & $0.15 \pm 0.053$ & $0.09-0.19$ & $0.12 \pm 0.017$ & $0.11-0.14$ & $0.08 \pm 0.026$ & $0.06-0.11$ \\
\hline & 20 & $0.12 \pm 0.021$ & $0.10-0.14$ & $0.03 \pm 0.026$ & $0.01-0.06$ & $0.02 \pm 0.010$ & $0.01-0.03$ \\
\hline & 30 & $0.09 \pm 0.001$ & $0.06-0.13$ & $0.02 \pm 0.010$ & $0.01-0.03$ & BDL & N/A \\
\hline Superficial & 0 & $0.14 \pm 0.040$ & $0.10-0.18$ & $0.11 \pm 0.061$ & $0.07-0.18$ & $0.12 \pm 0.010$ & $0.11-0.13$ \\
\hline \multirow[t]{3}{*}{ sediments } & 10 & $0.12 \pm 0.035$ & $0.10-0.16$ & $0.02 \pm 0.012$ & $0.01-0.03$ & $0.01 \pm 0.001$ & $0.009-0.011$ \\
\hline & 20 & $0.03 \pm 0.026$ & $0.01-0.06$ & $0.03 \pm 0.021$ & $0.02-0.05$ & $0.02 \pm 0.01$ & $0.01-0.03$ \\
\hline & 30 & BDL & N/A & BDL & N/A & BDL & N/A \\
\hline Fish & 0 & $0.11 \pm 0.014$ & $0.09-0.15$ & $0.08 \pm 0.010$ & $0.07-0.09$ & $0.08 \pm 0.036$ & $0.05-0.12$ \\
\hline (Oreochromis & 10 & $0.04 \pm 0.030$ & $0.02-0.07$ & $0.03 \pm 0.035$ & $0.01-0.07$ & BDL & N/A \\
\hline \multirow[t]{2}{*}{ nilotica) } & 20 & $\mathrm{BDL}$ & $\mathrm{N} / \mathrm{A}$ & $\mathrm{BDL}$ & N/A & $\mathrm{BDL}$ & N/A \\
\hline & 30 & $\mathrm{BDL}$ & N/A & BDL & N/A & BDL & N/A \\
\hline Yams & 0 & $0.30 \pm 0.173$ & $0.20-0.50$ & $0.28 \pm 0.026$ & $0.26-0.31$ & $0.29 \pm 0.066$ & $0.23-0.36$ \\
\hline (Dioscorea & 10 & $0.24 \pm 0.060$ & $0.18-0.30$ & $0.20 \pm 0.030$ & $0.17-0.23$ & $0.15 \pm 0.046$ & $0.11-0.20$ \\
\hline \multirow[t]{2}{*}{ alata) } & 20 & $0.12 \pm 0.020$ & $0.10-0.14$ & $0.10 \pm 0.01$ & $0.06-0.15$ & $0.01 \pm 0.003$ & $0.008-0.013$ \\
\hline & 30 & $\mathrm{BDL}$ & $\mathrm{N} / \mathrm{A}$ & BDL & N/A & BDL & N/A \\
\hline
\end{tabular}

S.D-Standard deviation, BDL-below method detection limit of $0.001 \mathrm{mg} / \mathrm{L}$ or $0.001 \mu \mathrm{gg}^{-1}$, N/A-Not applicable

Mean values in bold are higher than the maximum US EPA compliance limit of $0.002 \mathrm{mg} / \mathrm{L}$ for mercury in drinking water 


\section{Table 2 (on next page)}

Total mercury content of water, sediments, fish and yams in artisanal and small-scale gold mining areas reported by global studies 
1 Table 2. Total mercury content of water, sediments, fish and yams in artisanal and small-scale gold mining areas reported by global

2 studies

\begin{tabular}{|c|c|c|c|c|}
\hline Study area & Sample (matrix) & Total mercury content $\left(\mathrm{mg} / \mathrm{L}\right.$ or $\left.\mu g^{-1}\right)$ & Year ${ }^{1}$ & Authors \\
\hline \multirow[t]{3}{*}{ Manyera River, Nigeria } & Sediment & 0.018 & \multirow{3}{*}{2013} & \multirow{3}{*}{ Oladipo et al. } \\
\hline & Water & 0.021 & & \\
\hline & Fish (Heterotis niloticus) & 0.008 & & \\
\hline \multirow[t]{2}{*}{ River Kaduna, Nigeria } & Water & Range: $1.72-2.50$ & \multirow[b]{2}{*}{2007} & \multirow[t]{2}{*}{ Mahre et al. } \\
\hline & Fisheries and aquatic life & Range:0.0001-0.001 & & \\
\hline Pra river basin, Ghana & Sediment & Average: 0.265 & 2006 & Donkor et al. \\
\hline $\begin{array}{l}\text { Rwamagasa artisanal gold } \\
\text { mining area, Tanzania }\end{array}$ & $\begin{array}{l}\text { Sediments } \\
\text { (a) Uvinza on the } \\
\text { Malagarasi river } \\
\text { (b) Ilagala } \\
\text { Yams }\end{array}$ & $\begin{array}{l}\text { Range: } 0.00017 \text { to } 0.00024 \\
\text { Range: } 0.10 \text { to } 0.66 \\
\text { Range: } 0.007 \text { to } 0.092\end{array}$ & 2005 & Taylor et al. \\
\hline Nambija, Ecuadorian Amazon & Sediment & Range: $0.7-9.3$; background 0.5 & 2003 & Ramirez-Requelme et al. \\
\hline $\begin{array}{l}\text { Tongguan, Shaanxi Province, } \\
\text { Peoples` Republic of China }\end{array}$ & Sediment & Range: $0.3-0.9$ & 2006 & Feng et al. \\
\hline Buyat Bay, Indonesia & Sediment & Range: $0.010-0.017$ & 2010 & Lasut et al. \\
\hline Phichit Province, Thailand & Sediment & Range: 0.096-0.402 & 2007 & Pataranawata et al. \\
\hline $\begin{array}{l}\text { Tatelu gold mining area, } \\
\text { Indonesia }\end{array}$ & Freshwater fish & $\begin{array}{l}0.58 \pm 0.44 \text {; greater than } 45 \% \text { of fish had } \\
\text { total mercury above WHO maximum limit }\end{array}$ & 2006 & Castilhos et al. \\
\hline Nilambur, Kerala, India & Sediment & Range: $0.103-0.468$ & 2012 & Mohan et al. \\
\hline \multirow{4}{*}{$\begin{array}{l}\text { Namukombe stream, Busia } \\
\text { gold district, Uganda }\end{array}$} & Water & Range: below detection limit to 1.21 & \multirow{4}{*}{2019} & \multirow[t]{4}{*}{ Current study } \\
\hline & Sediment & Range: below detection limit to 0.14 & & \\
\hline & Fish (Oreochromis nilotica) & Range: below detection limit to 0.11 & & \\
\hline & Yams (Dioscorea alata) & Range: below detection limit to 0.30 & & \\
\hline
\end{tabular}

3 'Years reported represent the year the data were published, with most data collected 1-2 years prior to publication 


\section{Table 3 (on next page)}

Toxicity indices of mercury from consumption of fish and yams and contact with sediments from Namukombe stream by adults 
Table 3. Toxicity indices of mercury from consumption of fish and yams and contact with sediments from Namukombe stream by adults Distance $\quad$ Fish (Oreochromis nilotica Lin.)

\begin{tabular}{|c|c|c|c|c|c|c|c|c|c|c|c|c|c|c|c|c|c|c|}
\hline \multirow{3}{*}{$\begin{array}{l}\text { Distance } \\
\text { (m) }\end{array}$} & \multicolumn{6}{|c|}{ Fish (Oreochromis nilotica Lin.) } & \multicolumn{6}{|c|}{ Yams (Dioscorea alata) } & \multicolumn{6}{|c|}{ Superficial sediments } \\
\hline & \multicolumn{3}{|c|}{ EDI $(\mu \mathrm{g} / \mathrm{kg} / \mathrm{day})$} & \multicolumn{3}{|c|}{ THQ } & \multicolumn{3}{|c|}{ EDI $(\mu \mathrm{g} / \mathrm{kg} / \mathrm{day})$} & \multicolumn{3}{|l|}{ THQ } & \multicolumn{3}{|c|}{$\operatorname{ADD}_{\text {therm }}(\mu \mathrm{g} / \mathrm{kg} /$ day $) \times 10^{-6}$} & \multicolumn{3}{|c|}{ THQ $\times 10^{-4}$} \\
\hline & $\begin{array}{l}\text { Up } \\
\text { sluice }\end{array}$ & $\begin{array}{l}\text { Middle } \\
\text { sluice }\end{array}$ & $\begin{array}{l}\text { Down } \\
\text { Sluice }\end{array}$ & $\begin{array}{l}\text { Up } \\
\text { sluice }\end{array}$ & $\begin{array}{l}\text { Middle } \\
\text { sluice }\end{array}$ & $\begin{array}{l}\text { Down } \\
\text { sluice }\end{array}$ & $\begin{array}{l}\text { Up } \\
\text { sluice }\end{array}$ & $\begin{array}{l}\text { Middle } \\
\text { sluice }\end{array}$ & $\begin{array}{l}\text { Down } \\
\text { sluice }\end{array}$ & $\begin{array}{l}\text { Up } \\
\text { sluice }\end{array}$ & $\begin{array}{l}\text { Middle } \\
\text { sluice }\end{array}$ & $\begin{array}{l}\text { Down } \\
\text { sluice }\end{array}$ & $\begin{array}{l}\text { Up } \\
\text { sluice }\end{array}$ & $\begin{array}{l}\text { Middle } \\
\text { sluice }\end{array}$ & $\begin{array}{l}\text { Down } \\
\text { sluice }\end{array}$ & $\begin{array}{l}\text { Up } \\
\text { sluice }\end{array}$ & $\begin{array}{l}\text { Middle } \\
\text { sluice }\end{array}$ & $\begin{array}{l}\text { Do } \\
\text { slu }\end{array}$ \\
\hline 0 & 0.0183 & 0.0133 & 0.0133 & 0.0458 & 0.0333 & 0.0333 & 0.1279 & 0.1194 & 0.1237 & 0.320 & 0.299 & 0.309 & 7.105 & 5.583 & 6.090 & 7.105 & 5.583 & 6.0 \\
\hline 10 & 0.0067 & 0.0049 & N/A & 0.0168 & 0.0123 & $\mathrm{~N} / \mathrm{A}$ & 0.1023 & 0.0853 & 0.0639 & 0.256 & 0.213 & 0.160 & 6.090 & 1.015 & 0.5075 & 6.090 & 1.015 & \\
\hline 20 & N/A & $\mathrm{N} / \mathrm{A}$ & $\mathrm{N} / \mathrm{A}$ & N/A & $\mathrm{N} / \mathrm{A}$ & N/A & 0.0512 & 0.0426 & 0.0042 & 0.128 & 0.105 & 0.011 & 1.523 & 1.523 & 1.015 & 1.523 & 1.523 & 1.0 \\
\hline 30 & $\mathrm{~N} / \mathrm{A}$ & $\mathrm{N} / \mathrm{A}$ & N/A & N/A & N/A & $\mathrm{N} / \mathrm{A}$ & N/A & N/A & $\mathrm{N} / \mathrm{A}$ & N/A & $\mathrm{N} / \mathrm{A}$ & $\mathrm{N} / \mathrm{A}$ & $\mathrm{N} / \mathrm{A}$ & N/A & N/A & N/A & N/A & $\mathrm{N} / \mathrm{H}$ \\
\hline
\end{tabular}

3 EDI -Estimated daily intake, THQ-Target Hazzard Quotient (unitless), ADD-average daily dose, N/A-Not applicable 


\section{Table 4 (on next page)}

Toxicity indices of mercury from consumption of fish and yams and contact with sediments from Namukombe stream by children 
1

2

Table 4. Toxicity indices of mercury from consumption of fish and yams and contact with sediments from Namukombe stream by children

\begin{tabular}{|c|c|c|c|c|c|c|c|c|c|c|c|c|c|c|c|c|c|c|}
\hline \multirow{3}{*}{$\begin{array}{c}\text { Distance } \\
\text { (m) }\end{array}$} & \multicolumn{6}{|c|}{ Fish (Oreochromis nilotica Lin.) } & \multicolumn{6}{|c|}{ Yams (Dioscorea alata) } & \multicolumn{6}{|c|}{ Superficial sediments } \\
\hline & \multicolumn{3}{|c|}{ EDI $(\mu \mathrm{g} / \mathrm{kg} / \mathrm{day})$} & \multicolumn{3}{|c|}{ THQ } & \multicolumn{3}{|c|}{ EDI $(\mu \mathrm{g} / \mathrm{kg} / \mathrm{day})$} & \multicolumn{3}{|c|}{ THQ } & \multicolumn{3}{|c|}{$\operatorname{ADD}_{\text {therm }}(\mu \mathrm{g} / \mathrm{kg} / \mathrm{day}) \times 10^{-6}$} & \multicolumn{3}{|c|}{ THQ $\times 10^{-4}$} \\
\hline & $\begin{array}{l}\text { Up } \\
\text { sluice }\end{array}$ & $\begin{array}{l}\text { Middle } \\
\text { sluice }\end{array}$ & $\begin{array}{l}\text { Down } \\
\text { sluice }\end{array}$ & $\begin{array}{l}\text { Up } \\
\text { sluice }\end{array}$ & $\begin{array}{l}\text { Middle } \\
\text { sluice }\end{array}$ & $\begin{array}{l}\text { Down } \\
\text { sluice }\end{array}$ & $\begin{array}{l}\text { Up } \\
\text { sluice }\end{array}$ & $\begin{array}{l}\text { Middle } \\
\text { sluice }\end{array}$ & $\begin{array}{l}\text { Down } \\
\text { sluice }\end{array}$ & $\begin{array}{l}\text { Up } \\
\text { sluice }\end{array}$ & $\begin{array}{l}\text { Middle } \\
\text { sluice }\end{array}$ & $\begin{array}{l}\text { Down } \\
\text { sluice }\end{array}$ & $\begin{array}{l}\text { Up } \\
\text { sluice }\end{array}$ & $\begin{array}{l}\text { Middle } \\
\text { sluice }\end{array}$ & $\begin{array}{l}\text { Down } \\
\text { sluice }\end{array}$ & $\begin{array}{l}\text { Up } \\
\text { sluice }\end{array}$ & $\begin{array}{l}\text { Middle } \\
\text { sluice }\end{array}$ & $\begin{array}{l}\text { Do } \\
\text { slui }\end{array}$ \\
\hline 0 & 0.073 & 0.053 & 0.053 & 0.183 & 0.133 & 0.133 & 0.394 & 0.367 & 0.381 & 0.985 & 0.918 & 0.953 & 5.227 & 4.107 & 4.480 & 5.227 & 4.107 & 4.4 \\
\hline 10 & 0.027 & 0.020 & N/A & 0.0665 & 0.05 & $\mathrm{~N} / \mathrm{A}$ & 0.315 & 0.262 & 0.197 & 0.788 & 0.655 & 0.493 & 4.480 & 0.747 & 0.373 & 4.480 & 0.747 & $0.3^{\prime}$ \\
\hline 20 & $\mathrm{~N} / \mathrm{A}$ & N/A & N/A & N/A & $\mathrm{N} / \mathrm{A}$ & N/A & 0.158 & 0.131 & 0.013 & 0.395 & 0.328 & 0.033 & 1.120 & 1.120 & 0.747 & 1.120 & 1.120 & 0.7 \\
\hline 30 & N/A & N/A & N/A & N/A & N/A & N/A & N/A & N/A & N/A & N/A & N/A & N/A & N/A & N/A & N/A & N/A & N/A & $\mathrm{N} / A$ \\
\hline
\end{tabular}

3 EDI -Estimated daily intake, THQ-Target Hazzard Quotient (unitless), ADD-average daily dose, N/A-Not applicable 


\section{Table 5 (on next page)}

Bioconcentration factor, Biota to Sediment Accumulation Factor, Contamination factor and Geoaccumulation Index for the investigated matrices 
Table 5. Bioconcentration factor, Biota to Sediment Accumulation Factor, Contamination factor and Geoaccumulation Index for the investigated matrices from Namukombe stream

\begin{tabular}{|c|c|c|c|c|c|c|c|c|c|c|c|c|}
\hline \multirow[t]{2}{*}{ Distance (m) } & \multicolumn{3}{|c|}{ Bioconcentration factor } & \multicolumn{3}{|c|}{ Biota to sediment accumulation factor } & \multicolumn{3}{|c|}{ Contamination factor } & \multicolumn{3}{|c|}{ Geoaccumulation index } \\
\hline & $\begin{array}{c}\text { Up } \\
\text { sluice }\end{array}$ & $\begin{array}{l}\text { Middle } \\
\text { sluice }\end{array}$ & $\begin{array}{l}\text { Down } \\
\text { sluice }\end{array}$ & $\begin{array}{c}\text { Up } \\
\text { sluice }\end{array}$ & $\begin{array}{c}\text { Middle } \\
\text { sluice }\end{array}$ & Down sluice & $\begin{array}{c}\text { Up } \\
\text { sluice }\end{array}$ & $\begin{array}{l}\text { Middle } \\
\text { sluice }\end{array}$ & Down sluice & Up sluice & Middle sluice & Down sluice \\
\hline 0 & 0.091 & 0.444 & 0.800 & 0.786 & 0.727 & 0.667 & 0.56 & 0.44 & 0.48 & -1.423 & -1.771 & -1.644 \\
\hline 10 & 0.267 & 0.250 & N/A & 0.333 & 1.500 & $\mathrm{~N} / \mathrm{A}$ & 0.48 & 0.08 & 0.04 & -1.644 & -4.230 & -5.233 \\
\hline 20 & $\mathrm{~N} / \mathrm{A}$ & $\mathrm{N} / \mathrm{A}$ & $\mathrm{N} / \mathrm{A}$ & $\mathrm{N} / \mathrm{A}$ & $\mathrm{N} / \mathrm{A}$ & $\mathrm{N} / \mathrm{A}$ & 0.12 & 0.12 & 0.08 & -3.644 & -3.644 & -4.230 \\
\hline 30 & $\mathrm{~N} / \mathrm{A}$ & $\mathrm{N} / \mathrm{A}$ & $\mathrm{N} / \mathrm{A}$ & $\mathrm{N} / \mathrm{A}$ & N/A & $\mathrm{N} / \mathrm{A}$ & N/A & N/A & $\mathrm{N} / \mathrm{A}$ & $\mathrm{N} / \mathrm{A}$ & $\mathrm{N} / \mathrm{A}$ & $\mathrm{N} / \mathrm{A}$ \\
\hline
\end{tabular}

